\title{
The Effects of International Financial Integration in a Model with Heterogeneous Firms and Credit Frictions
}

\author{
Christiane Clemens Maik Heinemann
}




\title{
The Effects of International Financial Integration in a Model with Heterogeneous Firms and Credit Frictions $^{\dagger}$
}

\author{
Christiane Clemens* \\ Bielefeld University \\ and CESifo
}

\author{
Maik Heinemann** \\ University of Potsdam
}

September 26, 2013

\begin{abstract}
This paper examines the consequences of international financial integration in a two-sector heterogeneous-agent dynamic general equilibrium model of occupational choice with financial constraints and idiosyncratic risks. We discuss the macroeconomic and distributional effects of financial market integration for small economies which differ only with respect to the tightness of constraints on the domestic credit market. The results contribute to an explanation for the 'Lucas paradox', i.e. the empirical observation of capital flowing from poor to rich countries, where lending countries are characterized by tighter domestic constraints and lower capital returns. Capital market liberalization goes along with adjustments towards the world return. Capital-exporting countries experience an increase in GNP, whereas the GDP effect is of ambiguous sign and driven by the tightness of the domestic credit market. Countries with less tight constraints or unlimited access to external business financing loose throughout integration due to a decline in aggregate output and a very unequal distribution of welfare gains and losses in the underlying heterogeneous-agent economy. We find that international integration is only beneficial for economies where financial constraints on entrepreneurial activity are very tight. Here, we observe an accumulation-driven rise in the entrepreneurship rate, overall positive output effects and welfare gains for all members of society.
\end{abstract}

Keywords: financial constraints, financial market integration, international capital flows, heterogeneous agents, occupational choice

JEL classification: C68, D3, D8, D9, F4, G0, J24

\footnotetext{
†The authors would like to thank Mathias Hoffmann, Vincenzo Quadrini, and Michael Woodford for helpful comments on earlier versions of this paper. We also thank seminar participants at CESifo Munich, ETH Zurich, University of Zurich, ZEW Mannheim, DEGIT XV, CEF 2013, and EEA and Econometric Society meetings in Atlanta and Barcelona.

*Bielefeld University, Germany, cclemens@uni-bielefeld.de

**University of Potsdam, Germany, maik.heinemann@uni-potsdam.de
} 


\section{Introduction}

For the past twenty years the United States, the United Kingdom, and Australia have experienced a sustained rise in their current account deficits, while many emerging economies from East Asia, and in particular China throughout recent years, have either drastically reduced their deficit or even built up substantial surpluses (see Figure 1). Prasad et al. (2006) find perverse patterns of capital flows in the 2000s from poor to rich countries. The empirically observed pattern of international capital flows contradicts standard neoclassical theory, which predicts that capital should flow from more to less developed countries. A growing body of literature explains this empirical evidence, conveniently dubbed as 'Lucas paradox' (referring to the influential work by Lucas, 1990), with the presence of borrowing constraints in poorer countries; see e.g. Gertler and Rogoff (1990), Boyd and Smith (1997), and Matsuyama (2004, 2005), or more recently Caballero et al. (2008), Mendoza et al. (2009), and Sandri (2009).

Our paper contributes to this strand of research. We present a two-sector neoclassical heterogeneous-agent dynamic general equilibrium model of occupational choice with financial constraints and idiosyncratic risks, which allows us to relate the pattern of international capital movements to cross-country differences in financial market imperfections. We find that countries may as well as not benefit from financial market integration, the outcome depending on the tightness of domestic constraints and the resulting capital return of a small economy under autarky relative to the world real interest rate. Notably, it is the more constrained economy which claims welfare gains for all members of society.

As well-known from the literature, countries facing tighter credit constraints have lower domestic interest rates and generally become net-exporters of capital if capital markets open for international borrowing and lending. In our model economy, international capital flows are only indirectly capable of mitigating adverse output effects from financial constraints on domestic credit markets. Lending countries benefit from financial integration in terms of a higher GNP, but it is the underlying distribution of income and wealth which determines whether or not this translates into an overall welfare gain. We find that lending countries with less tight constraints or unlimited access to external business financing loose throughout integration due to a decline in aggregate output and a very unequal distribution of welfare gains and losses in the underlying heterogeneous-agent economy.

The model economy consists of two sectors of production: an unconstrained corporate sector and a non-corporate 'small business' sector, where firm owners produce intermediate goods and are subject to financial constraints. This is consistent with previous work by Bernanke et al. (1998) suggesting that smaller firms face tighter constraints than large firms. We assume that financial constraints in our model arise from limited commitment of business owners and not from lack of financial intermediaries or under-developed financial markets. It is important to stress that financial integration in our model neither helps to alleviate agency problems nor directly facilitates small firms' access to external funding. The international capital flows of our model explicitly originate from cross-country differences in the tightness of financial 

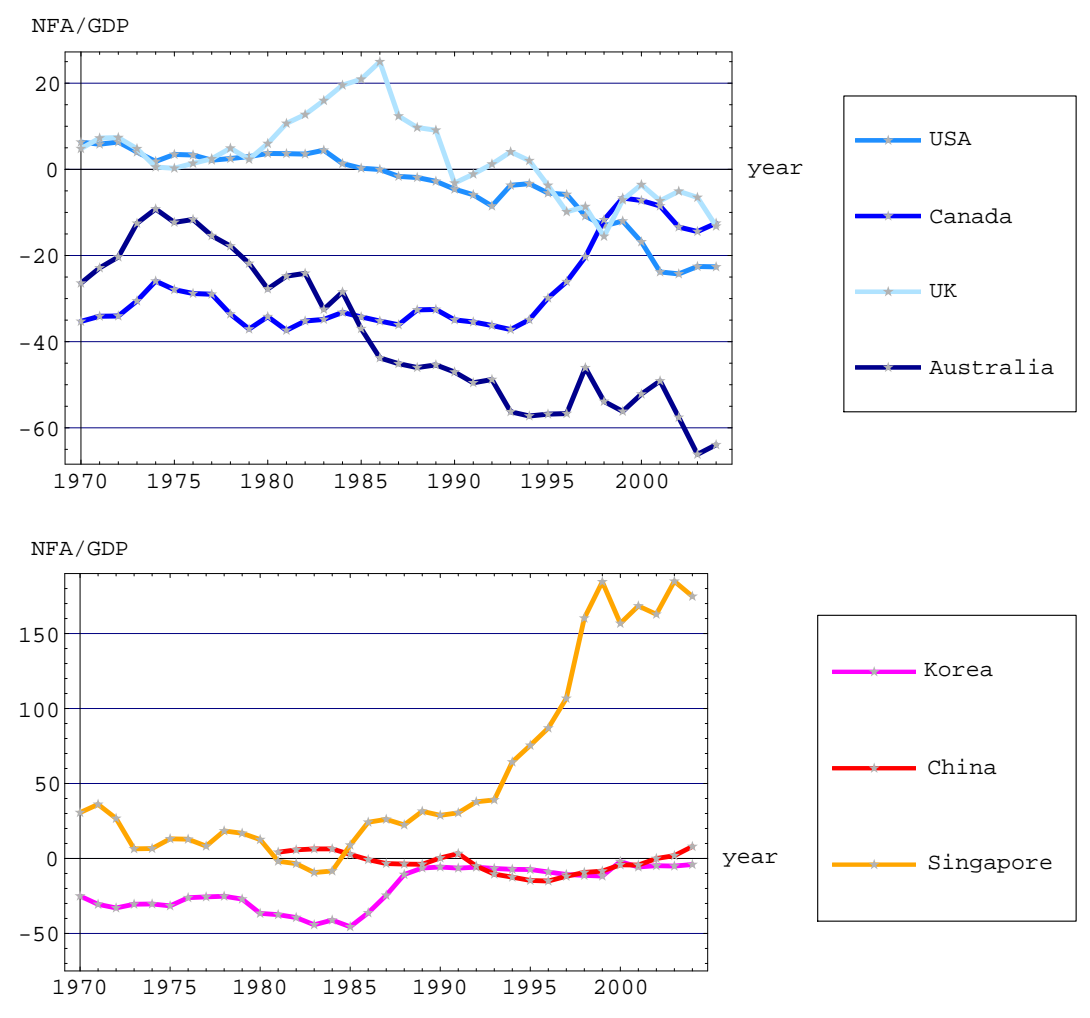

Figure 1: Net Foreign Asset Positions (data from Lane and Milesi-Ferretti, 2007)

constraints. The latter are persistent, because the primary source of credit market imperfection is limited commitment of borrowers. In this context, we do not think it convincing to assume that foreign lenders and financial intermediaries are less risk averse or more effective in monitoring and law enforcement than their domestic counterparts.

Credit market frictions are a threefold impediment to economic activity in our model economy: Firstly, agents are restrained from smoothing their intertemporal consumption path by borrowing and lending. Common to Huggett (1993)-Aiyagari (1994)-type economies, the agents then undertake buffer-stock savings to self-insure on intertemporal markets against the non-diversifiable income risk. ${ }^{1}$ Because a business owner's wealth also serves as collateral for external financing, individual accumulation is important for occupational choice. Secondly, credit-constrained business owners are not able to operate at their profit-maximizing firm size, which reduces industry output and subsequently aggregate income. That credit frictions restrain entrepreneurship is broadly acknowledged throughout the theoretical and empirical literature; see e.g. Evans and Leighton (1989), Evans and Jovanovic (1989),

\footnotetext{
${ }^{1}$ Our analysis is also embedded in literature on dynamic general equilibrium models with idiosyncratic risks and borrowing constraints which stress the importance of buffer-stock saving and entrepreneurial activity for the explanation of the empirically observed accumulation patterns; see e.g. Quadrini (2000), Meh (2005), Boháček (2006, 2007), Cagetti and De Nardi (2006a,b), Clemens and Heinemann (2010).
} 
Holtz-Eakin et al. (1994b), and Gentry and Hubbard (2004). Thirdly, industryspecific financial constraints lead to an inefficient allocation of capital across sectors. The share of capital employed in the unconstrained sector is too large compared to a frictionless economy. Straightforwardly, with diminishing returns to capital, the equilibrium real interest rate of a closed economy facing comparably tight constraints is likely to be lower than the world rate of return (cf. Caballero et al., 2008). Going from autarky to financial openness, the real interest rates rises to the global equilibrium rate and the economy becomes a net-lender. Capital is reallocated towards those foreign countries who face less tight constraints and originally higher domestic rates of return.

Comparing steady states of the closed vis-à-vis the financially integrated (albeit constrained) economy, we find that rising interest rates trigger wealth accumulation. Household wealth serves as collateral for external funding of non-corporate enterprises. Wealthier households are more likely to be members of the entrepreneurial class than poorer ones, which is consistent with recent empirical findings (Quadrini, 1999; Holtz-Eakin et al., 1994a). The increase in the interest rate partially relieves business owners from financing constraints and stimulates economic activity, even though the fundamental market conditions remain unchanged. We observe an accumulation-driven rise in the entrepreneurship rate. But only in the heavily constrained economy the expansion in the mass of firms actually turns into an increase in sectoral output, because shrinking firm sizes bring on a counter-acting effect. The latter prevails in less constrained economies and-in combination with reduced capital inputs due to outbound capital flows-leads towards an overall decline in GDP.

Our analysis extends the contribution of Mendoza et al. (2009), who explain the 'upstream' pattern of international capital flows primarily with excess saving due to the presence of borrowing constraints and idiosyncratic risk in the household sector in a standard incomplete markets economy. Other recent work in this area includes Angeletos and Panousi (2011), Antunes and Cavalcanti (2014), Buera and Shin (2009), and Sandri (2009). The authors agree that welfare consequences of international integration in standard incomplete market models are large when compared to representative agent economies. They, too, find ambiguous aggregate welfare effects and large distributional effects of financial integration. However, the standard incomplete markets approach suffers from the drawback that, given less developed countries are characterized by tighter borrowing constraints and/or higher risk, overaccumulation leads to higher per capita incomes. Mendoza et al. (2009) circumvent this counterfactual outcome by assuming exogenously given productivity differences. Our paper pursues a different approach. Similar to the contributions of Angeletos and Panousi (2011) and Buera and Shin (2009), we take account of financial constraints in production, which is an empirically important issue.

We develop a model economy which is closely related to modern growth theory and draw on previous work (Clemens, 2006, 2008; Clemens and Heinemann, 2006, 2010). We combine occupational choice under risk à la Kihlstrom and Laffont (1979) and Kanbur (1979) with the two-sector approach of Romer (1990), but without en- 
dogenous growth. The risk-averse agents choose between two occupations in each period of time, either setting up a an enterprise in the intermediate goods industry or being worker in the production of a final good. All households are subject to an idiosyncratic income risk which cannot be pooled. Managerial ability and productivity as a worker follow independent random processes. Entrepreneurial activity is rewarded with a higher expected income. An entrepreneur employs capital from own and borrowed resources and can be subject to financial constraints. Due to the two-sector general equilibrium nature of our model, the optimal business size and the demand for credit are endogenously determined. There is no aggregate risk.

The model is broadly consistent with macro data from industrialized countries. Naturally, the model cannot draw a realistic picture of the economy over the entire domain of financial constraints under consideration. For this reason, we define a benchmark economy with an empirically plausible debt-equity ratio, and calibrate the model to match the standard macroeconomic key variables.

Our paper does not address the role of intermediaries for the growth process and the relationship between financial market integration and development; cf. Greenwood and Jovanovic (1990), Bencivenga and Smith (1993), King and Levine (1993a,b), Boyd and Smith (1997), Gourinchas and Jeanne (2006, 2007), Aoki et al. (2009), Buera and Shin (2009). The general insight from this body of literature is that capital account liberalization speeds up the process of convergence and promotes growth.

The paper is organized as follows: Section 2 develops the two-sector model. We describe the closed-economy equilibrium associated with a stationary earnings and wealth distribution. Since the formal structure of the model does not allow for analytical solutions, we perform numerical simulations of a calibrated model in order to examine the general equilibrium effects of financial market integration. Section 3 gives details on calibration and discusses the numerical results. Section 4 provides a welfare analysis and raises politico-economic issues. Section 5 concludes.

\section{A Two-Sectoral Model with Financial Market Imperfections}

\subsection{Production}

We consider a small economy with two sectors engaged in the production of a homogenous final output good $Y{ }^{2}$ Firms of the corporate sector are perfectly competitive. They employ capital $K_{F}$, labor $L$, and a variety of intermediate goods $x(i), i \in[0, \lambda]$ to produce final output $Y$ according to the neoclassical generalized CES-technology ${ }^{3}$

$$
Y=\left(K_{F}^{\gamma} L^{1-\gamma}\right)^{1-\alpha} \int_{0}^{\lambda} x(i)^{\alpha} \mathrm{d} i, \quad \alpha, \gamma \in(0,1) .
$$

The intermediate goods are close but imperfect substitutes. Each variety $i$ is identified with a single producer in the intermediate goods industry. $\lambda$ then represents the en-

\footnotetext{
${ }^{2}$ We draw from previous work (Clemens and Heinemann, 2010) for the general layout of the model. Closely related contributions are Quadrini (2000); Angeletos and Panousi (2011).

${ }^{3}$ All macroeconomic variables are time-dependent. For notational convenience, we will drop the explicit time-notation unless necessary. If needed, the / symbol denotes next period variables.
} 
trepreneurship rate of the economy and is endogenously determined in equilibrium, once households have made a choice on their occupation. We assume that the capital stock depreciates at the constant rate $\delta$. The price of final output is normalized to unity. $p(i)$ is the price of intermediate good $i$.

In each period, the profit of the representative firm in the corporate sector, $\Pi$, is given by

$$
\Pi=Y-w L-(r+\delta) K_{F}-\int_{0}^{\lambda} p(i) x(i) \mathrm{d} i .
$$

The profit-maximizing factor demand for capital, labor and intermediate inputs are determined in accordance with marginal productivity theory

$$
\begin{aligned}
K_{F} & =(1-\alpha) \gamma \frac{Y}{r+\delta}, \\
L & =(1-\alpha)(1-\gamma) \frac{Y}{w}, \\
x(i) & =K_{F}^{\gamma} L^{1-\gamma}\left(\frac{\alpha}{p(i)}\right)^{\frac{1}{1-\alpha}},
\end{aligned}
$$

Equations (3) and (4) represent the final good sector demand for capital services and labor in efficiency units respectively. $r$ and $w$ denote the equilibrium factor prices.

The producer of intermediate good $x(i)$ faces the isoelastic demand function (5). The non-corporate sector comprises a large number of monopolistic firms. Each firm is owned by an entrepreneur and produces a single variety of the intermediate good, using capital, $k(i)$, as sole input according to the constant returns to scale technology

$$
x(i)=\theta(i)_{e} k(i) .
$$

Firm owners differ with respect to their entrepreneurial talents, measured by the idiosyncratic productivity shock $\theta(i)_{e}$, which we assume to be non-diversifiable and uncorrelated across firms. We assume that firm-specific factor demand takes place after the draw of nature has occurred, such that there is no under-employment of capital. Maximization of profit

$$
\pi\left(k(i), \theta(i)_{e}\right)=p(i) x(i)-(r+\delta) k(i)
$$

leads to the following decision expressed in terms of the optimal firm size $k(i)^{*}$ :

$$
k(i)^{*}=L \theta(i)^{\frac{\alpha}{1-\alpha}}\left(\frac{\gamma w}{(1-\gamma)(r+\delta)}\right)^{\gamma}\left(\frac{\alpha^{2}}{r+\delta}\right)^{\frac{1}{1-\alpha}} .
$$

The optimal firm size declines with rising costs of capital and is larger for higher realizations of individual productivity $\theta(i)_{e}$, implying that more productive business owners have a larger demand for capital.

\subsection{Capital market and financial constraints}

We assume that firms of the final goods sector have unrestricted access to the capital market. Contrary, business owners in the intermediate goods industry face financial constraints. The credit market is imperfect because lenders are unable to enforce 
loan-repayment due to limited commitment of borrowers (cf. Banerjee and Newman, 1993). Loan amounts are limited and individual wealth serves as collateral. In case of default, the lender is able to seize a fraction of the borrowers gross capital income $(1+r) a(i)$ and will lend only the amount consistent with the borrower's incentivecompatibility constraint, such that it is in the borrower's interest to repay the loan. There is not credit default in equilibrium. ${ }^{4}$ We also assume that international integration does not directly relax financing constraints for business owners because financial integration in our model neither helps to alleviate agency problems nor directly facilitates small firms' access to external funding.

Let $k(i)=a(i)+b(i)$ be the firm size an entrepreneur is able to operate at from own wealth $a(i)$ and borrowed resources $b(i)$. Depending on the level of individual entrepreneurial wealth, the operating firm size $k(i)$ falls short of the profit-maximizing firm size $k(i)^{*}$, if access to credit is limited and financial constraints become binding. Incentive-compatibility requires a self-enforcing contract. It is never optimal for the borrower to default, if

$$
\pi(i)+(1+r) a(i) \geqslant \pi(i)+b(i)(1+r)+(1-\phi)(1+r) a(i)
$$

which boils down to

$$
b(i) \leqslant \phi a(i) .
$$

The maximum possible loan is proportional to the business owner's wealth $a(i)$. The parameter $\phi$ can be viewed as a credit multiplier. Credit constraints relax for rising $\phi$ and effectively vanish for very large $\phi$. The limiting cases reflect complete enforceability $(\phi \rightarrow \infty)$ or no enforceability $(\phi=0)$.

Utilizing the collateral constraint (9), enables us to write the operating firm size of entrepreneur $i$ with productivity $\theta(i)_{e}$ and wealth $a(i)$ as follows:

$$
k\left(\theta(i)_{e}, a(i)\right)=\min \left[k(i)^{*},(1+\phi) a(i)\right] .
$$

Summing up, demand for capital in the closed economy is from firms of the final good industry and from credit-constrained entrepreneurs. Regarding the capital supply side, this comprises workers' savings and entrepreneurial wealth from those business owners, whose personal assets exceed their respective optimal capital input. We assume that there is no difference between borrowing and lending rates, meaning that all capital is supplied to the (domestic or international) capital market at the equilibrium interest rate $r$.

Because our focus lies on the effects of financial market integration, we assume labor to be immobile and output goods to be non-tradeable. Hence, all trade between internationally integrated economies is financial.

\subsection{Households and occupational choice}

We assume a continuum $[0,1]$ of infinitely-lived risk-averse households. All households are endowed with a unit of raw labor, which they either supply inelastically to

\footnotetext{
${ }^{4}$ We do not explicitly model financial intermediaries.
} 
the labor market or use for running and managing a business. Households differ with respect to the realization of idiosyncratic shocks to labor efficiency or entrepreneurial productivity respectively. In order to have wage incomes less risky than profits, we assume that worker productivities are more evenly distributed than entrepreneurial skills. There is no market for pooling individual income risks. Every period, each household decides anew on his occupation. Regarding the timing of events, we assume that occupational choice takes place before the resolution of uncertainty in the respective period. Occupational choice is irreversible in the same period. There is no aggregate risk.

We assume that labor efficiency $\theta_{w}$ evolves according to a serially correlated firstorder stochastic process with $h=1, \ldots, H$ states, $\theta_{w, h}>0$. Likewise, entrepreneurial productivity $\theta_{e}$ evolves according to a serially correlated first-order stochastic process with $h=1, \ldots, H$ different states $\theta_{e, 1}, \ldots, \theta_{e, H}, \theta_{e, h}>0$. Realizations from the two stochastic processes are mutually independent to capture the idea that a presently high productivity in the one occupation not necessarily indicates an equally high productivity in the other. The associated probabilities are summarized in a $H \times H$ transition matrices $P_{j, j^{\prime}}$ describing the transition from productivity state $\theta_{j, h}$ to state $\theta_{j^{\prime}, h^{\prime}}$ for $h, h^{\prime}=1, \ldots, H, j, j^{\prime}=e, w$.

Each household $i$ has preferences over consumption and maximizes discounted expected lifetime utility

$$
\mathrm{E}_{0} \sum_{t=0}^{\infty} \beta^{t} U\left[c_{t}(i)\right]
$$

$\mathrm{E}_{0}$ is the expectation operator conditional on information available at date 0 and $\beta \in(0,1)$ denotes the discount factor. Individuals are identical with respect to their preferences regarding momentary consumption $c(i)$ which are described by constant relative risk aversion measured by the parameter $\rho$

$$
U[c(i)]=\frac{c(i)^{1-\rho}}{1-\rho} \quad \text { for } \rho>0, \rho \neq 1
$$

and $\ln c_{t}(i)$ for $\rho=1$.

Income and wealth heterogeneity in our model stem from uninsurable shocks and credit market imperfections. We assume that households are subject to borrowing constraints, restricting their means to smooth their consumption flow. Typical for standard incomplete market models, this gives rise to overaccumulation, because individuals undertake buffer-stock saving (Carroll, 1997) in their desire to protect themselves against fluctuations in consumption. ${ }^{5}$ We assume that individual asset holdings are bounded from below and set the lowest possible wealth level to $\underline{a}=0$.

In what follows $V^{w}\left(a(i), \theta(i)_{w}\right)$ denotes the maximized value function of a household currently a worker with wealth $a$ and a given productivity level $\theta_{w}$. If the agent

\footnotetext{
${ }^{5}$ This implies the counterfactual result that for two countries, which differ only with respect to the tightness of borrowing constraints, the more constrained economy accumulates more capital and therefore has a higher GDP per capita than the less constrained one. Mendoza et al. (2009) circumvent this result by assuming exogenously given differences in aggregate productivity. Our model generates results which are consistent with the empirical evidence that more constrained economies typically are poorer than the less constrained ones, due to the presence of financial constraints in production, the endogenously determined entrepreneurship rate, and endogenous adjustments in firm sizes.
} 
remains a worker, his future productivity is determined according to the transition matrix $P_{w, w}$. If he decides to change occupations, he draws from the time-invariant distribution of entrepreneurial skills. The next period productivity $\theta_{e}^{\prime}$ is determined by the transition matrix $P_{w, e}$.

The maximized value function for an individual currently a worker is given by

$$
\begin{aligned}
V^{w}\left(a(i), \theta(i)_{w}\right)= & \max _{c(i) \geqslant 0, a(i)^{\prime} \geqslant a, q(i)^{\prime} \in\{0,1\}}\{U[c(i)] \\
& \left.+\beta\left(1-q(i)^{\prime}\right) \mathrm{E}_{w, w}\left[V^{w}\left(a(i)^{\prime}, \theta(i)_{w}^{\prime}\right)\right]+\beta q(i)^{\prime} \mathrm{E}_{w, e}\left[V^{e}\left(a(i)^{\prime}, \theta(i)_{e}^{\prime}\right)\right]\right\}
\end{aligned}
$$

s.t. $\quad a(i)^{\prime}=(1+r) a(i)+\theta(i)_{w} w-c(i)$.

$q$ is a boolean variable, taking the value 0 if the agent decides to stay in the present occupation, and taking the value 1 , if he decides to leave. The optimal decision associated with problem (11) is described by the the policy function $a(i)_{w}^{\prime}=A_{w}\left(a(i), \theta(i)_{w}\right)$ and a rule on the future professional state $q(i)_{w}^{\prime}=Q_{w}\left(a(i), \theta(i)_{w}\right)$.

For business owners let accordingly $V^{e}\left(a(i), \theta(i)_{e}\right)$ denote the maximized value function of an entrepreneur with wealth $a$ in productivity state $\theta_{e}$. His future productivities are determined by either $P_{e, e}$ or $P_{e, w}$, depending on his occupational choice. The intertemporal problem of an entrepreneur can be written as

$$
\begin{aligned}
V^{e}\left(a(i), \theta(i)_{e}\right)= & \max _{c(i) \geqslant 0, a(i)^{\prime} \geqslant a, q(i)^{\prime}\{0,1\}}\{U[c(i)] \\
& \left.+\beta\left(1-q(i)^{\prime}\right) \mathrm{E}_{e, e}\left[V^{e}\left(a(i)^{\prime}, \theta(i)_{e}^{\prime}\right)\right]+\beta q(i)^{\prime} \mathrm{E}_{e, w}\left[V^{w}\left(a(i)^{\prime}, \theta(i)_{w}^{\prime}\right)\right]\right\} \\
\text { s.t. } \quad a(i)^{\prime}= & (1+r) a(i)+p(x(i)) x\left(\theta(i)_{e}, k(i)\right)-(r+\delta) k(i)-c(i) \\
k(i)= & \min \left[k(i)^{*},(1+\phi) a(i)\right]
\end{aligned}
$$

The optimal decision is described the policy function $a(i)_{e}^{\prime}=A_{e}\left(a(i), \theta(i)_{e}\right)$ and the decision rule $q(i)_{e}^{\prime}=Q_{e}\left(a(i), \theta(i)_{e}\right)$.

\subsection{Stationary recursive equilibrium in the closed economy}

Definition 1 A stationary recursive competitive general equilibrium is defined by equilibrium factor prices $w, r$, policy functions $A_{w}, A_{e}$, decision rules $Q_{w}, Q_{e}$ with associated value functions $V_{w}$, $V_{e}$ such that the following conditions hold:

(i) The policy functions $A_{w}$ and $A_{e}$ and decision rules $Q_{e}$ and $Q_{e}$ solve the worker's or entrepreneur's optimization problem respectively.

(ii) Aggregate demand for consumption, labor, capital and intermediate goods is the aggregation of individual demands. Factor and commodity markets clear at constant equilibrium prices $w, r, p$. 
Table 1: Calibration Values

\begin{tabular}{|c|c|c|c|c|c|c|}
\hline \multicolumn{4}{|c|}{ Calibrated parameter } & \multicolumn{2}{|l|}{ Target } & \multirow{3}{*}{$\begin{array}{l}\text { Source } \\
\text { (Obstfeld, 1994; } \\
\text { King and Rebelo, 1999) }\end{array}$} \\
\hline \multirow{2}{*}{\multicolumn{4}{|c|}{$\begin{array}{l}\text { Technology } \\
\alpha \quad \gamma\end{array}$}} & Interest rate $r$ & $2-4 \%$ & \\
\hline & & & & & & \\
\hline \multirow[t]{2}{*}{0.33} & 0.06 & 0.1 & & Factor income shares & & \\
\hline & & & & labor & 0.63 & (King and Rebelo, \\
\hline \multicolumn{2}{|c|}{ Preferences } & & & profit & 0.22 & 1999, PSID) \\
\hline \multirow[t]{2}{*}{2.0} & $\begin{array}{c}\beta \\
0.91\end{array}$ & & & capital & 0.15 & \\
\hline & & & & Gini index of wealth & $0.6-0.7$ & \\
\hline \multicolumn{3}{|l|}{ Shocks } & $\rho_{e}$ & Income persistence & $\rho_{j}=0.9$ & (Guvenen, 2009; \\
\hline 0.0171 & 0.9 & 0.855 & 0.9 & Log wage income risk & 0.3 & Storesletten et al., 2004) \\
\hline \multirow{2}{*}{\multicolumn{4}{|c|}{$\begin{array}{l}\text { Financial frictions } \\
\quad \phi\end{array}$}} & Entrepreneurship rate & $15-25 \%$ & (GEM, 2005) \\
\hline & & & & Exit/ entry rates & $20-35 \%$ & $\begin{array}{l}\text { (Quadrini, 2000; Vale, } \\
\text { 2006; Aghion et al., 2007) }\end{array}$ \\
\hline
\end{tabular}

(iii) The stationary distribution $\Gamma\left(a, \theta_{e}, \theta_{w} ; w, r, p, \phi\right)$ of agents over individual wealth holdings, occupations and associated productivities is the fixed point of the law of motion which is consistent with the individual decision rules and equilibrium prices. The distribution $\lambda, 1-\lambda$ of agents over occupations is time-invariant.

We obtain aggregate labor supply by summing up individual labor supply in efficiency units over the population share of $1-\lambda$ workers. Capital supply equals mean wealth holdings and meets capital demand from the two sectors of production. The equilibrium entrepreneurship rate $\lambda$ and the stationary distribution of entrepreneurial productivities determine the aggregate supply of intermediate goods

\section{Numerical Analysis}

\subsection{Calibration}

In order to evaluate the macroeconomic effects of financial integration, we calibrate a benchmark model to match standard macro data for the U.S. or the average EU15. We set the measure of relative risk aversion $\rho$ and the time discount factor $\beta$ in accordance with the literature (cf. Obstfeld, 1994; King and Rebelo, 1999). The parametric specifications are summarized in Table 1. The productivity parameters $\alpha$ and $\gamma$ are chosen to generate empirically plausible income shares with close to two thirds of income accruing to labor. PSID data report a income share for entrepreneurs of around $22 \%$, which we match in an economy without financial constraints. The rate of capital depreciation is set to $10 \%$.

Labor efficiency $\theta_{w}$ and entrepreneurial productivity $\theta_{e}$ follow a lognormal $A R(1)$ process with normalized mean $\mathrm{E}\left[\theta_{j}\right]=1, j=e, w$, which in continuous space is given 
by:

$$
\ln \theta_{j}^{\prime}=-1 /\left(1+\rho_{j}\right) \frac{\sigma_{j}^{2}}{2}+\rho_{j} \ln \theta_{j}+\varepsilon, \quad \varepsilon \sim \mathcal{N}\left(0, \sigma_{\varepsilon, j}^{2}\right) .
$$

The $A R(1)$ process is approximated in discrete state-space by a five-state Markov chain using the method proposed by Rouwenhorst (1995). The transition matrices for individuals who decide to change their occupations are derived from the stationary distributions of the Markov processes, such that, e.g., the probability for a worker to draw the highest state of entrepreneurial productivity is given by the stationary (unconditional) probability of this state.

We follow the literature in assuming a high persistence of income shocks and set $\rho_{j}=0.9 . \sigma_{\varepsilon, w}^{2}$ is chosen to generate a standard deviation of wage incomes close to 0.3. This specification matches empirical evidence reported by Storesletten et al. (2001) and Guvenen (2009). Given the relatively scarce evidence on idiosyncratic profit risk, we choose a higher variance in order to reproduce the larger risk associated with entrepreneurial activity and to generate empirically plausible entrepreneurship rates and Gini coefficients of wealth. In our simulated baseline model, the standard deviation of $\log$ profits is about three to four times the standard deviation of log wage incomes. Regarding the definition of entrepreneurship, we follow the notion that self-employment encompasses (OECD, 2000, Ch. 5, p. 191):

"...those jobs, where the remuneration is directly dependent upon the profits derived from the goods and services produced. The incumbents make the operational decisions affecting the enterprise, or delegate such decisions while retaining responsibility for the welfare of the enterprise."

Our model generates entrepreneurship rates around 20-25\%, which is at the upper range of values for OECD countries (including owner-managers), matching countries like New Zealand (20.8\%), Italy (24.8\%), or Spain (18.3\%), but also is empirically plausible for emerging economies; see also the annual Global Entrepreneurship Monitor (GEM 2005, Minniti et al.).

We consider three different values for the credit multiplier $\phi$. To mimic unlimited access to external financing $(\phi \rightarrow \infty)$ we find it sufficient in our simulations to choose $\phi=10^{32}$ as largest value, where effectively no entrepreneur is credit-constrained. The other two values are $\phi=0$ (no external financing) and $\phi=1$, i.e., the maximum operating capital is restricted to twice the business owner's individual asset holdings (cf. Evans and Jovanovic, 1989; Gentry and Hubbard, 2004).

The model is computed using the algorithm described in Clemens and Heinemann (2010).

\subsection{The role of entrepreneurial risk and financial frictions}

In this section, we investigate how either a change in idiosyncratic entrepreneurial risk or in the credit multiplier affects the macroeconomic equilibrium of the closed economy. Alternatively, the results can be interpreted as comparing two economies which differ only with respect to the size of business risk or the tightness of credit frictions. Our numerical results generate the empirically relevant and plausible outcome 
Table 2: Equilibrium Effects of Lower Entrepreneurial Risk

\begin{tabular}{l|cc|rl}
\hline \hline & $\begin{array}{c}\text { high risk } \\
\left(\sigma_{\varepsilon, e}^{2}=50 \sigma_{\varepsilon, w}^{2}\right)\end{array}$ & $\begin{array}{c}\text { low risk } \\
\left(\sigma_{\varepsilon, e}^{2}=10 \sigma_{\varepsilon, w}^{2}\right)\end{array}$ & & \\
\hline$G D P$ & 0.213 & 0.218 & +2.35 & $\%$ \\
entrepreneurship rate & 0.239 & 0.285 & +4.6 & $\mathrm{p} . p$. \\
$\varnothing$ firm size & 0.686 & 0.506 & -26.23 & $\%$ \\
$X=\int_{\lambda} x(i)^{\alpha} \mathrm{d} i$ & 0.255 & 0.269 & +5.49 & $\%$ \\
$K_{I}$ & 0.164 & 0.144 & -12.20 & $\%$ \\
$K_{F}$ & 0.061 & 0.053 & -13.11 & $\%$ \\
$L$ & 0.896 & 0.863 & -3.68 & $\%$ \\
real interest rate & 0.041 & 0.065 & +2.4. & $\mathrm{p} . p$. \\
wage rate & 0.150 & 0.159 & +6.00 & $\%$ \\
$\varnothing$ wage income & 0.176 & 0.191 & +8.52 & $\%$ \\
$\varnothing$ profit & 0.197 & 0.169 & -14.21 & $\%$ \\
$\varnothing$ wealth & 0.224 & 0.196 & -12.5 & $\%$ \\
$\varnothing$ worker wealth & 0.137 & 0.188 & +37.22 & $\%$ \\
$\varnothing$ business wealth & 0.503 & 0.219 & -56.46 & $\%$ \\
Gini & 0.601 & 0.494 & & \\
$\sigma$ (log wages) & 0.240 & 0.248 & & \\
$\sigma$ (log profits) & 0.909 & 0.434 & & \\
\hline \hline
\end{tabular}

that both factors-either an increase in risk or in the tightness of constraints-reduce aggregate output.

Table 2 presents the numerical results for the baseline model and a scenario characterized by lower risk for an economy, where firms in the intermediate goods industry are free from financial constraints $(\phi \rightarrow \infty)$. The parameter values are chosen such that the relative riskiness in terms of the standard deviation of log profits over log wage incomes in the low-risk scenario is about half of the baseline value. We skip the issue of firm financing for the moment because this allows us to highlight the additional economic channel which modeling a two-sectoral production structure brings to the standard incomplete markets model.

The household sector has significantly larger asset holdings in the high risk situation compared to the low risk one. This reflects the precautionary motive in saving which also is reinforced by the presence of borrowing constraints. In the standard incomplete markets economy, this 'overaccumulation' typically implies a larger economywide capital stock, an associated lower equilibrium real interest rate and a higher GDP per capita. Although our model replicates the first two effects, GDP in the high risk scenario is lower. The result is more in accordance with economic intuition, suggesting that larger risk harms economic performance.

The GDP effect can be traced back to adjustments in occupational choice leading to firm size and output responses in the intermediate goods industry. The overall contribution of intermediate goods, $X=\int_{0}^{\lambda} x(i)^{\alpha} \mathrm{d} i$, to output acts as a productivity variable for capital and labor inputs. It crucially depends on the equilibrium en- 
Table 3: Equilibrium Effects of varying the Tightness of Financial Constraints

\begin{tabular}{l|ccc|rl}
\hline \hline$\phi$ & $\infty$ & 1 & 0 & \multicolumn{2}{|c}{$\Delta(\phi: \infty \rightarrow 0)$} \\
\hline$G D P$ & 0.213 & 0.198 & 0.169 & -20.66 & $\%$ \\
entrepreneurship rate & 0.239 & 0.246 & 0.241 & -2.0 & $\mathrm{p} . p$ \\
$X=\int_{\lambda} x(i)^{\alpha} \mathrm{d} i$ & 0.255 & 0.238 & 0.202 & -20.78 & $\%$ \\
$\varnothing$ firm size & 0.686 & 0.566 & 0.421 & -38.63 & $\%$ \\
$K_{I}$ & 0.164 & 0.139 & 0.102 & -37.80 & $\%$ \\
$K_{F}$ & 0.061 & 0.064 & 0.069 & +13.11 & $\%$ \\
$L$ & 0.896 & 0.889 & 0.895 & -1.11 & $\%$ \\
real interest rate & 0.041 & 0.024 & -0.002 & -4.3 & p.p. \\
wage rate & 0.150 & 0.140 & 0.119 & -20.67 & $\%$ \\
$\varnothing$ wage income & 0.176 & 0.167 & 0.140 & -20.45 & $\%$ \\
$\varnothing$ profit & 0.197 & 0.195 & 0.190 & -3.55 & $\%$ \\
$\varnothing$ wealth & 0.224 & 0.204 & 0.171 & -23.66 & $\%$ \\
$\varnothing$ worker wealth & 0.137 & 0.087 & 0.056 & -59.12 & $\%$ \\
$\varnothing$ business wealth & 0.503 & 0.117 & 0.114 & -77.34 & $\%$ \\
Gini & 0.601 & 0.596 & 0.671 & & \\
$\sigma(\log$ wages $)$ & 0.240 & 0.242 & 0.244 & & \\
$\sigma(\log$ profits) & 0.909 & 0.897 & 0.902 & & \\
\hline \hline
\end{tabular}

trepreneurship rate and firm sizes in the industry. A decline in business risk has a markedly positive effect on the first. The relative riskiness of occupations in the low risk situation drops significantly and explains the shift in occupations. The associated decline in labor supply in the final goods industry implies a higher market clearing wage rate and also a comparable increase in average wage incomes and average wealth of workers.

The increase in the mass of business owners, however, is accompanied by a more than proportional decline in the average firm size which is due to higher interest rates following the reduction in aggregate wealth and capital supply, and the fact that the precautionary motive becomes less pressing. The increase in total output from the intermediate sector is responsible for net GDP growth, because it more than compensates for the relatively moderate decline in labor employment and the more pronounced reduction in capital inputs. ${ }^{6}$

We now give a brief review of how a change in the tightness of financial constraints effects the macroeconomic equilibrium. For a more detailed analysis, see Clemens and Heinemann (2010). We consider three different degrees of tightness, no credit, $\phi=0$, unlimited access, $\phi \rightarrow \infty$, and a credit multiplier of $\phi=1$. Table 3 summarizes the results. Although the value of $\phi$ is fixed exogenously, the credit demand as well as the magnitude of rationing is determined endogenously and depends on firm-specific factors, such as optimal business size (8), individual wealth, factor prices and the ability shocks.

\footnotetext{
${ }^{6}$ The contribution of factors to aggregate output can be decomposed by using the productivity weights $\gamma(1-\alpha)$ for capital and $(1-\gamma)(1-\alpha)$ for efficient labor.
} 
Financial frictions in the entrepreneurial sector dampen economic performance substantially, the aggregate output loss amounting to over $20 \%$, when comparing the frictionless vis-sa-vis the no-credit economy. This dampening effect transmits into all sectors of the economy, lowering the wage rate, average wage and profit incomes, and also reducing wealth holdings. The decline in the real interest rate is the consequence of capital now being shifted into the production of the final good, instead of being used in the intermediate goods industry. Capital inputs in the latter slump by roughly $40 \%$ if access to external financing is no longer available.

The entrepreneurship rate similar to the Gini coefficient of wealth shows a nonmonotonic response to tighter financial constraints. This can be explained by the equivalently non-monotonic change in the standard deviation of log profits, the lower value at $\phi=1$ being associated with higher incentives for business ownership. The riskiness of profits relative to wage incomes decreases throughout, which explains why the entrepreneurship rate stays above its level of the frictionless economy even when the financial market is completely closed.

\subsection{Macroeconomic effects of international financial integration}

We now turn to the macroeconomic effects of financial integration. As outlined before, we presume a small open economy where both output goods are non-tradeable and there is no labor migration. Hence, the macroeconomic effects of international integration are entirely driven by the initial wedge between the autarky and the world equilibrium interest rate and the associated inbound (or outbound) capital flows. We assume as a starting point for our analysis that the autarky equilibrium is characterized by a lower than the world interest rate, $r_{A}<r_{W}$, the subscripts denoting 'autarky' and 'world' respectively.

In the course of financial integration, the real interest rate immediately jumps to its world equilibrium value, triggering adjustments in capital demand from the final goods industry, in the allocation of capital between sector, in savings, and subsequently in occupational choice. We compare the steady state under autarky with the equilibrium allocation of the integrated economy for the three underlying values of credit frictions.

\section{Case I: Frictionless Entrepreneurial Sector $(\phi \rightarrow \infty)$}

Figure 2 summarizes the macroeconomic effects of international financial integration for the case of unlimited access to external financing in the intermediate goods industry. Here, our model generates results similar to those already described by Mendoza et al. (2009). The results for the small open economy are expressed in terms of the initial wedge between the real interest rate under autarky relative to the equilibrium world rate.

A country initially characterized by a lower domestic real interest rate will export capital and experiences a decrease in GDP. The returning interest payments raise GNP above the autarky level; see panels (a) and (b) of figure 2. We observe an increase in average wealth accumulation for rising interest rates which is typical for 


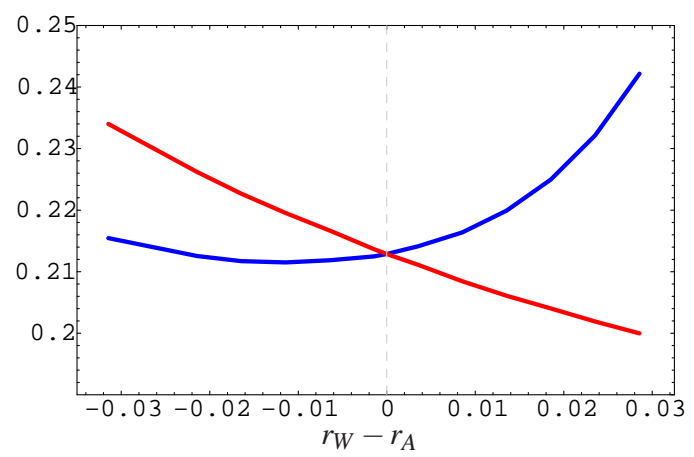

(a) GDP (red) and GNP (blue)

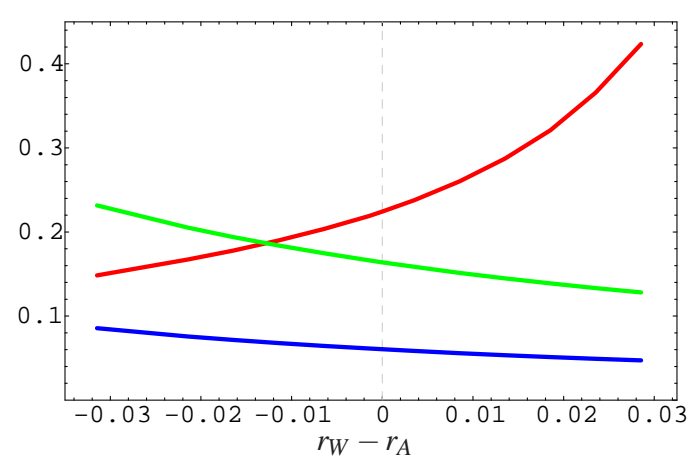

(c) Business wealth (green) and capital $K_{F}$ (blue), average wealth (red)

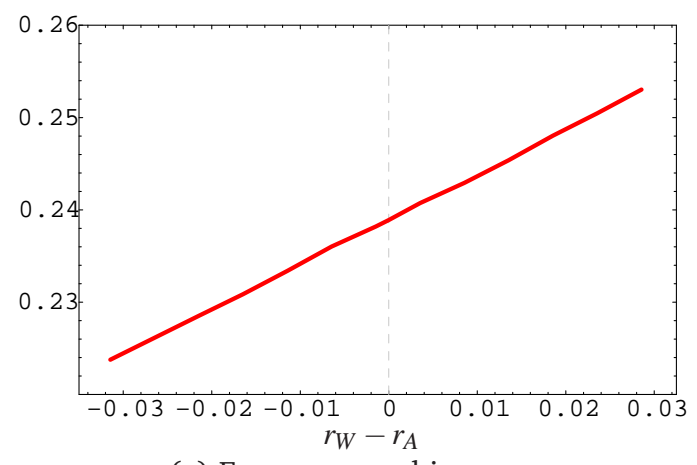

(e) Entrepreneurship rate

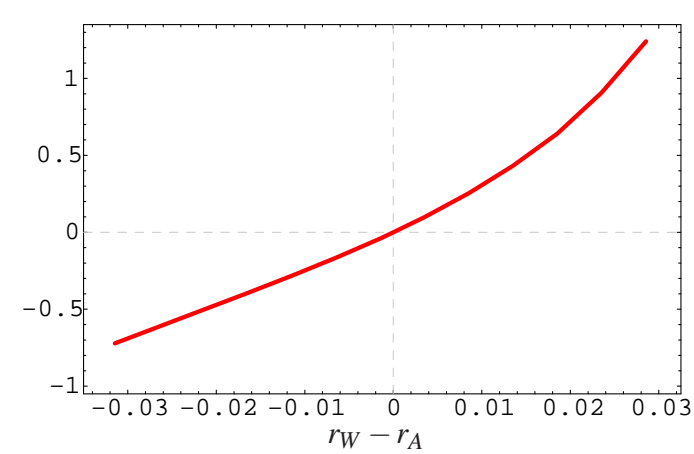

(b) NFA/GDP

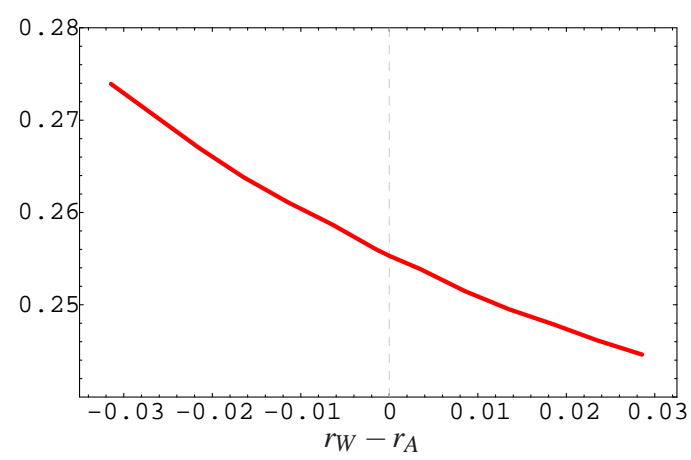

(d) Output $X$ of intermediate goods

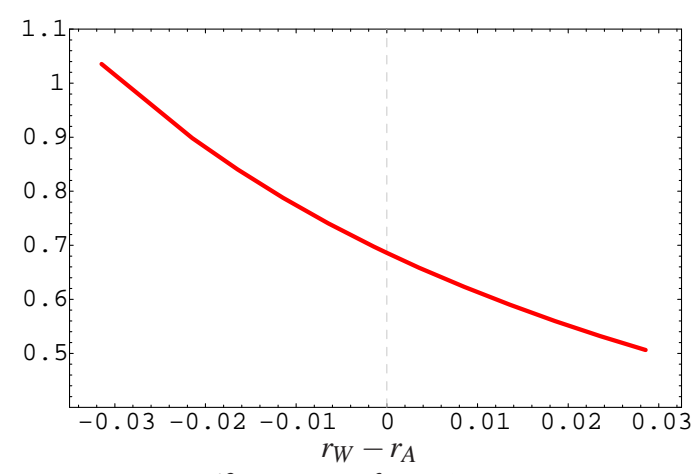

(f) Average firm size

Figure 2: Macroeconomic Effects of International Financial Integration, Case I

standard incomplete market economies, but more than the additionally accumulated capital is invested abroad, which becomes obvious from the decline in capital inputs in both domestic sectors of production. Accordingly, output in the intermediate goods industry declines and contributes to the decline in aggregate output.; see panels 2(c) and $2(\mathrm{~d})$.

The optimal firm size $k(i)^{*}$ declines for rising interest rates, which follows directly from (8). ${ }^{7}$ With unlimited access to external financing, each entrepreneur will be

\footnotetext{
${ }^{7}$ The elasticity of a change in the cost factor $r+\delta$ is easily derived from (8) and given by $\partial k^{*} / k^{*} \times$ $\partial(r+\delta) /(r+\delta)=-2$.
} 
Table 4: Macroeconomic Effects of Integration in the Constrained Economy

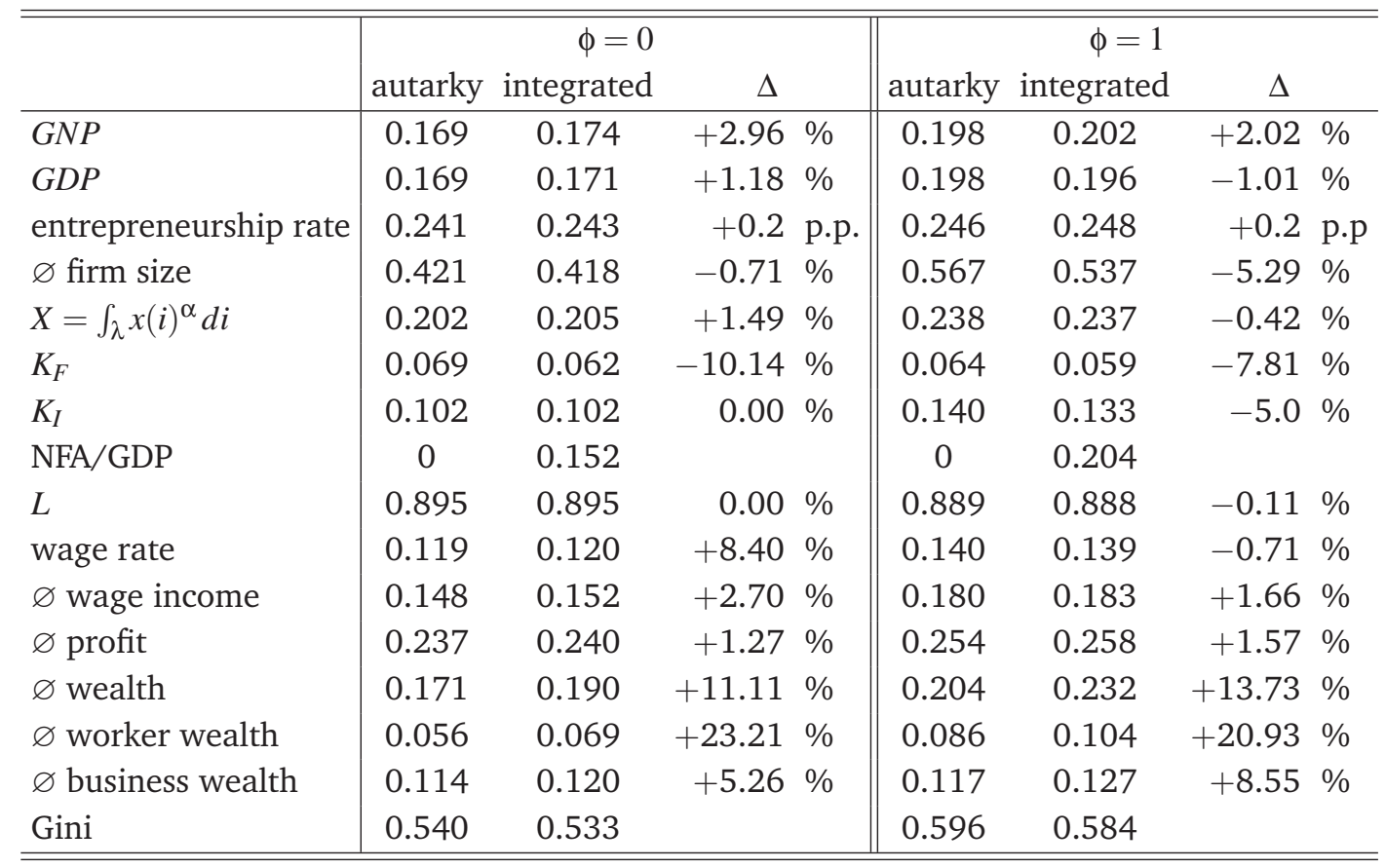

able to operate his business at a profit-maximizing scale, such that average firm sizes decline accordingly in the new steady state. Higher average wealth levels and a larger fraction of individual income derived out of safe returns domestic and abroad, attract more households into business ownership, giving an extra tinge to competition and consequently reducing business sizes.

Most effects reverse for a country initially characterized by a higher autarky capital return, that is $r_{A}>r_{W}$. All macroeconomic variables behave monotonously to a change in the steady state real interest rate, except for GNP. The country becomes a net-importer of capital and the rising international debt payments from a negative NFA interact with rising GDP to give GNP a $U$-shape contour.

\section{Case II: Financial Frictions in the Entrepreneurial Sector $(\phi \in\{0,1\})$}

We proceed with the case of a small economy, where business owners are subject to financial constraints. Whereas our findings for the frictionless economy by and large replicate the results already described in Mendoza et al. (2009) on a qualitative level, the additional presence of financial frictions in the business sector introduces a new economic channel which under certain conditions is capable of reversing the macroeconomic effects. Figure 3 and Table 4 display the results from our numerical simulations.

Generally, financial frictions cause an excess employment of physical capital in the production of the final good. Hence, the equilibrium interest rate under autarky is even lower than in the standard incomplete markets economy, where only households are subject to borrowing constraints. The demand for capital from the intermediate 


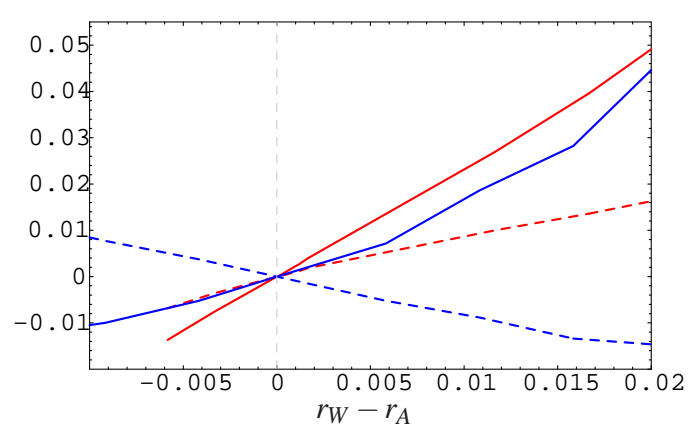

(a) GDP (dashed) and GNP (solid)

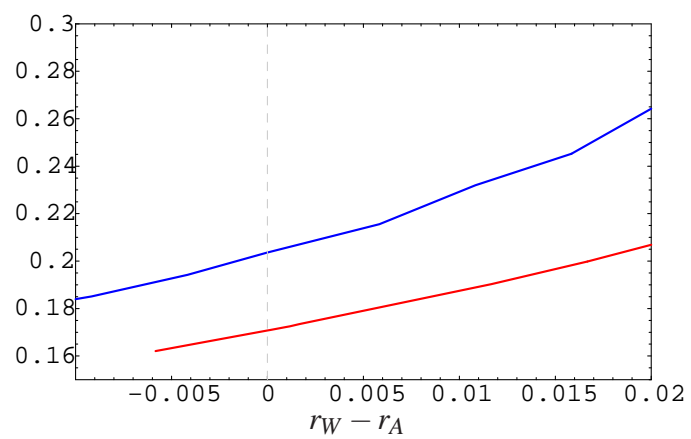

(c) Average wealth

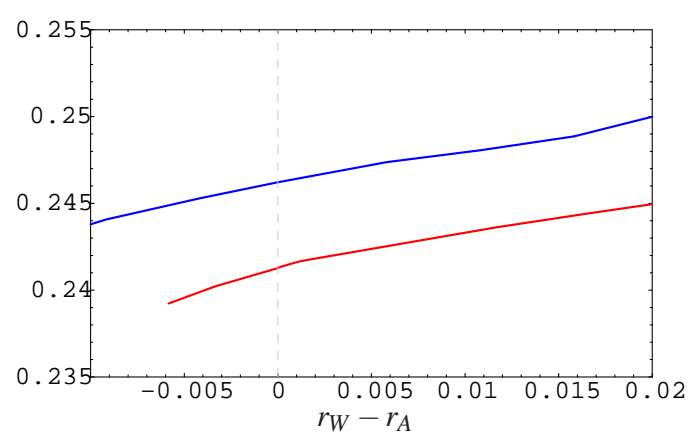

(e) Entrepreneurship rate

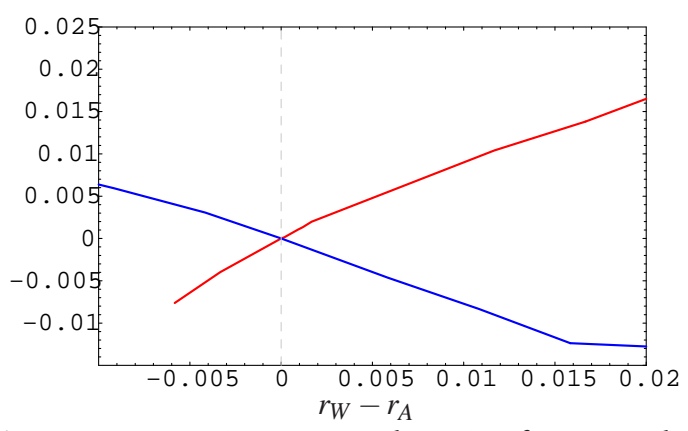

(g) Average wage incomes, \% deviation from autarky

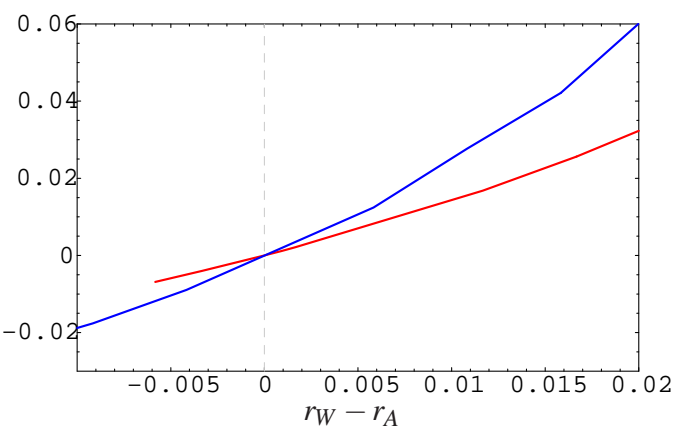

(b) NFA/GDP

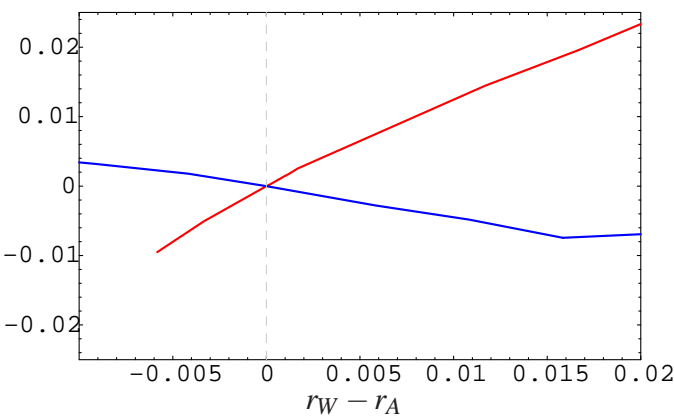

(d) Sector output $X$, \% deviation from autarky

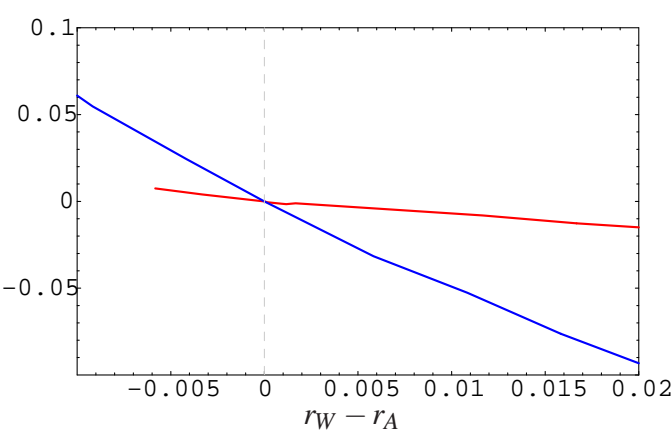

(f) Average firm size, \% deviation from autarky

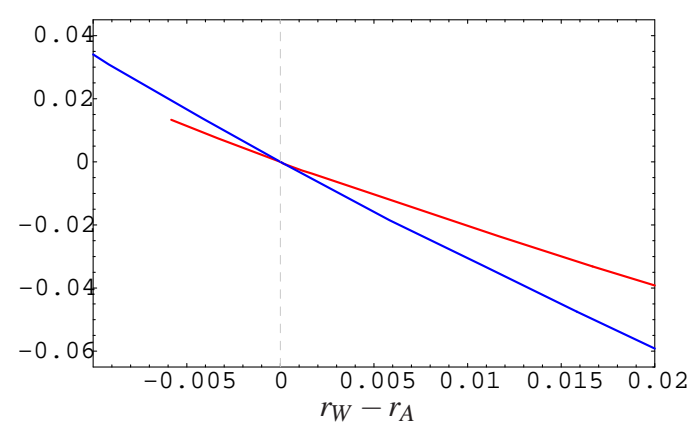

(h) Average profits, \% deviation from autarky

Figure 3: Macroeconomic Effects of International Financial Integration, Case II $\phi=0$ (red), $\phi=1$ (blue) 
goods industry potentially would be large, but cannot be satisfied due to limited or no access to credit. Business owners of this industry either produce at suboptimally small firm sizes,${ }^{8}$ or they have to be sufficiently wealthy to operate at the profit-maximizing level $k(i)^{*}$.

Allowing for international capital movements, a new steady state of this economy again is characterized by a jump of the domestic to the higher world interest rate, which triggers capital exports. Figure 3 illustrates the response of the macroeconomic variables to financial integration in terms of the initial wedge between the domestic real interest rate and the world return, whereas Table 4 gives the numerical results for a one percentage point increase in the interest rate starting from the autarky situation.

For $\phi=1$, we find no qualitative differences in results compared to the case of the frictionless economy. The equilibrium NFA/GDP ratio is positive and increasing in the initial spread $r_{W}-r_{A}$. GDP declines, whereas GNP increases. The entrepreneurship rate increases, while average business sizes and overall output in the intermediate sector fall. We observe a larger number of (albeit) smaller firms, who on average make less profit in the integrated economy. ${ }^{9}$ The adjustments in aggregate labor input are close to nil and the decline in the equilibrium wage rate is a consequence from downscaling the inputs of the two other factors of production $K_{F}$ and $X$.

Interestingly, the results for GDP, wages and output of the intermediate sector reverse, if we consider the case of a zero credit multiplier, $\phi=0$. As, by assumption, access to external financing is not easing up for business owners, average firm sizes do only respond very little to financial integration; see figure 3(f). Nevertheless, adjustments in asset holdings and occupational choice are important. Financial constraints affect especially households with little wealth. An increase in accumulation due to a higher world interest rate relaxes business owners' dependency on external financing. More agents move into entrepreneurship as households expand their wealth holdings; see figures 3(c) and 3(e). Table 4 shows that the increase in accumulation goes along with a reduction in wealth inequality.

Notably, whereas general equilibrium adjustments in firm sizes, business capital, and occupational choice lead to a decline in sectoral output $X$ for the case of $\phi=1$, they sum up to an increase in $X$ for the case of $\phi=0$. This also explains the associated increase in GDP and wage incomes. A completely constrained economy not only experiences an increase in GNP due to backflows of returns to foreign assets, but also reallocates factor inputs such that domestic output grows in comparison to the autarky state. International capital market liberalization primarily helps to overcome domestic financial constraints in an indirect way.

\subsection{Transitory Dynamics}

We now briefly discuss the transitional dynamics. The panels of Figure 4 show the adjustments paths of the macroeconomic variables towards the new steady state in

\footnotetext{
${ }^{8}$ This problem primarily hits the most talented with the highest realizations of $\theta(i)_{e}$.

${ }^{9}$ The country being a net-lender, overall average income for both occupational groups increases.
} 

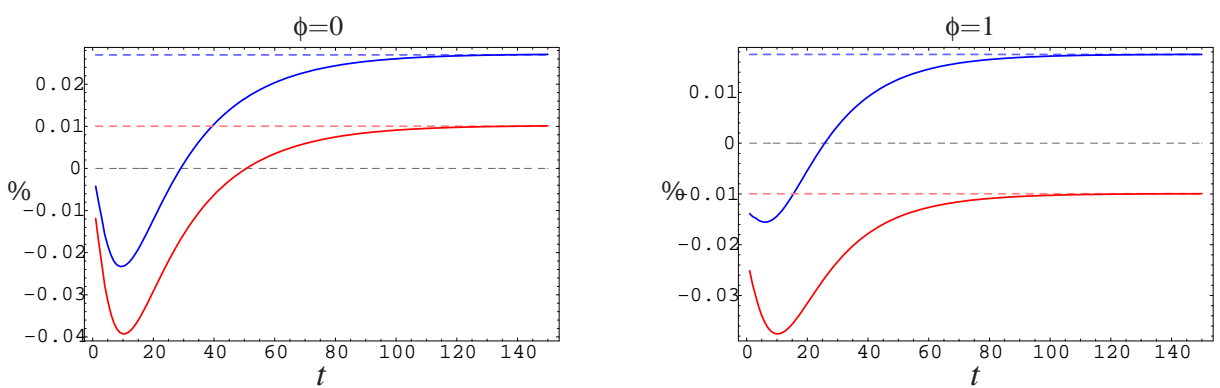

(a) GNP (blue), GDP (red)
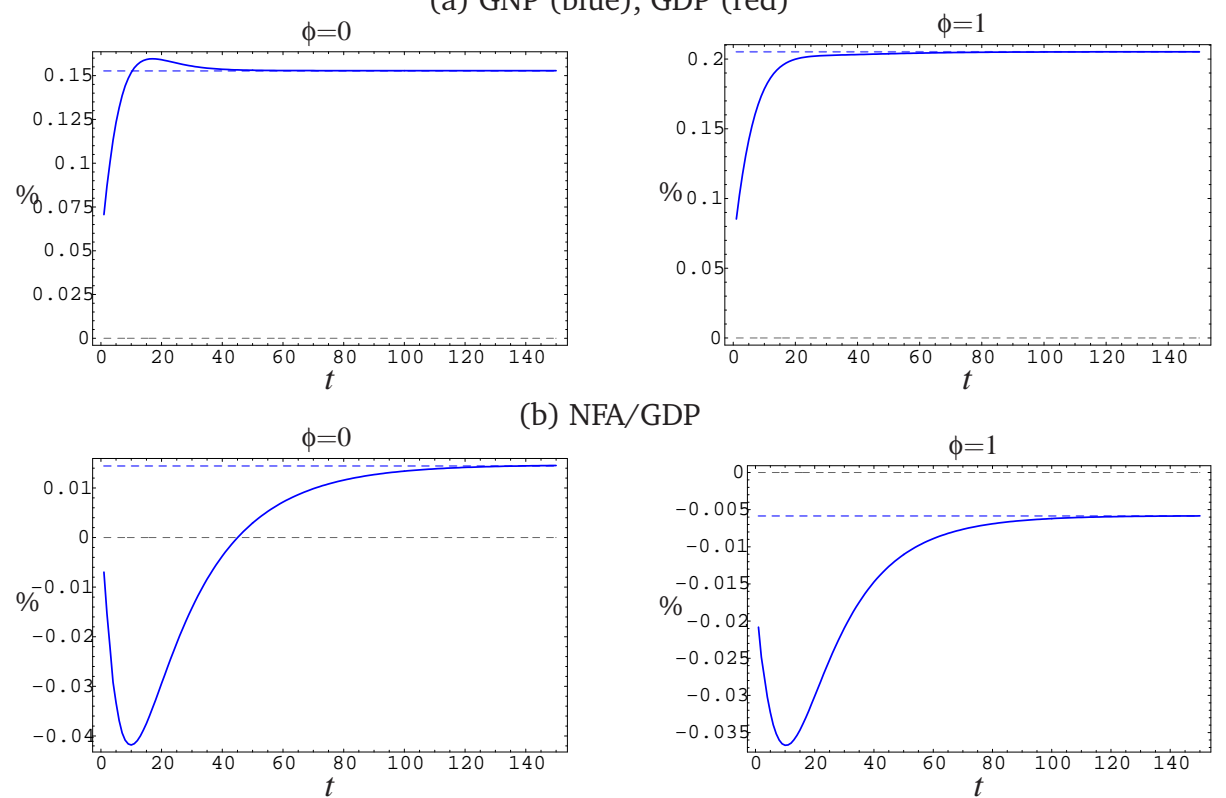

(c) Output intermediate sector
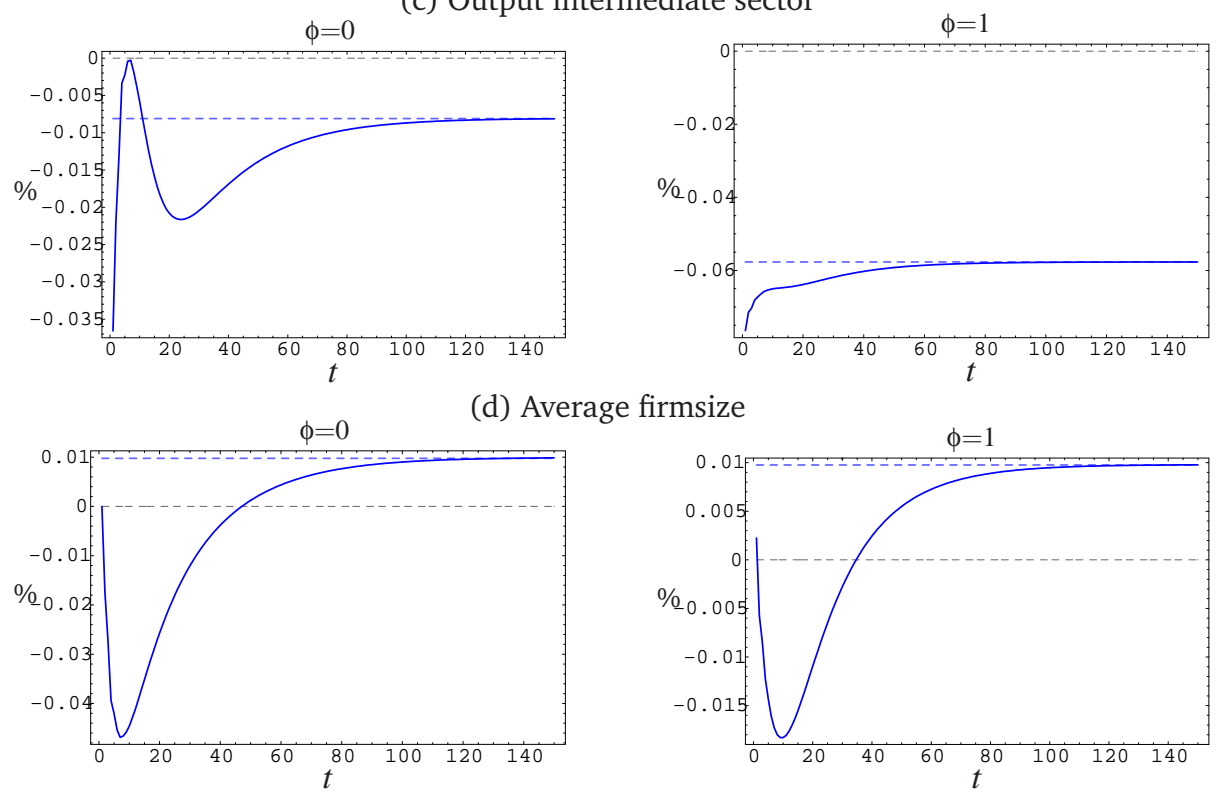

(e) Entrepreneurship rate

Figure 4: Transitory Dynamics (percentage deviation relative to autarky) 
terms of a percentage deviation from the old steady state over a time span of 140 periods, where transition is sufficiently completed. Our model essentially is a neoclassical one and displays the typical mechanics of adjustment. We focus on the case of financial constraints in the business sector, presenting only results for a debt-equity ratio of one and the complete absence of external financing.

The economy heavily employs capital in the production of the final good in the closed economy. With the world interest rate being larger than the domestic one under autarky, the necessary adjustment in marginal productivity requires a reduction in capital inputs, and excess supply in physical capital is shifted abroad. Consequently, output in both sectors of production as well as the average firm size in the intermediate goods industry show an immediate downward jump as the net foreign asset position jumps upward for outbound capital flows. The economy continues to export capital during the early phase of transition, which explains the ongoing drop in output.

The rise in the real interest rate triggers accumulation. The household sector holds an increasing amount of wealth (not displayed here). ${ }^{10}$ Ultimately, the accumulation effect prevails and explains the turning points in figures 4(a), 4(c), and 4(d). With the rising entrepreneurship rate, total output in the intermediate sector starts to expand in the medium run. Intermediate goods substitute for lower capital inputs in the final output sector. Subsequently, GDP and GNP grow towards their new steady state levels.

As can be seen in Figure 4 the response of sectoral output and occupational choice to financial integration is more pronounced for the case of no credit-availability, $\phi=0$, whereas capital exports relative to GDP and the firm size effect are smaller in magnitude. For the net foreign asset position and average firm size we even observe an overshooting throughout transition. A comparison between the left hand and right hand panels in Figures 4(a) and 4(c) also demonstrates quite nicely that the overall GDP gain for the case of $\phi=0$ can be traced back to the total output expansion in the intermediate goods industry, where the new steady state lies above the autarky level in this case and below for $\phi=1$.

\section{Welfare Analysis}

We employ a utilitarian welfare measure, aggregating individual welfare gains (or losses) over all agents in the economy. The individual welfare effect is measured by a compensating variation, i. e., the consumption amount necessary to compensate the household for financial integration, leaving her indifferent between autarky and the integrated economy.

Our welfare measure accounts for the transitory adjustments between the two steady states. We calculate the change in consumption for an individual with wealth $a(i)$, occupation $j$ and associated productivity $\theta(i)_{j}$, necessary to equate the value

\footnotetext{
${ }^{10}$ Average wealth holdings grow monotonously during transition for all levels of constraints under consideration.
} 
functions $V^{A}\left(a(i), \theta(i)_{j}\right), V^{I}\left(a(i), \theta(i)_{j}\right)$, where the superscripts denote autarky and integration.

$$
\Delta c^{A}(i)=\left[\frac{V^{A}\left(a(i), \theta(i)_{j}\right)}{V^{I}\left(a(i), \theta(i)_{j}\right)}-1\right] c^{A}(i)
$$

The amount $\Delta$ leaves the consumer indifferent between the two allocations under comparison. Taking expectations with respect to the stationary probability measure $\Gamma\left(a, \theta_{e}, \theta_{w} ; w, r, p, \phi\right)$ gives the aggregate welfare measure

$$
\frac{\Delta c^{A}}{c^{A}}=\frac{\mathrm{E} \Delta c^{A}(i)}{c^{A}}
$$

A positive value reflects a welfare gain associated with international financial integration.

Figure 5 displays the results of our numerical simulations. The left-hand panels show the welfare gains or losses arising for alternative world interest rates, for the society as a whole and decomposed with respect to the two classes of occupations. The respective equilibrium rate under autarky is represented by the vertical dashed line, where all lines intersect at zero level. The right hand panels show the population fractions supporting financial integration, again in total and decomposed with respect to occupational classes. These fractions represent the agents who actually benefit from international integration (or are at least indifferent towards it). Our discussion focuses on autarky situations, where the domestic equilibrium return is lower than the world rate.

Figures 5(a) and 5(b) show that the similarity of results from the analysis of the macroeconomic effects for the economy without financial frictions and the case of $\phi=1$ carries over to the welfare analysis. In an economy, where the domestic return is lower than the world rate, the society as a whole suffers a welfare loss from financial integration and both classes loose, if the initial interest rate spread is not too large.

For larger initial deviations between the autarky domestic rate and the world rate, the welfare loss turns into a welfare gain, see the left-hand panel of 5(b) for world rates close to five percent. To this extent, our model replicates results already known for the standard incomplete markets model, i.e. that welfare effects are nonmonotonic in policy measures; for corresponding results see Antunes and Cavalcanti (2014), or Domeij and Heathcote (2004) for the welfare effects of taxation. ${ }^{11}$ It follows from the unequal distribution of welfare gains and losses, which will be discussed in more detail below.

Interestingly, the welfare effect reverses for the case of complete financial frictions in the entrepreneurial sector. Here, the society benefits from international integration. If we compare the magnitude of welfare effects in the three cases, the loss from financial integration is most pronounced in the frictionless economy, less pronounced but still a loss for $\phi=1$ and a gain for $\phi=0$. Entrepreneurs suffer least, workers most

\footnotetext{
${ }^{11}$ The $U$-shape in welfare can already be observed for the no-risk Ramsey model with endowment heterogeneity.
} 

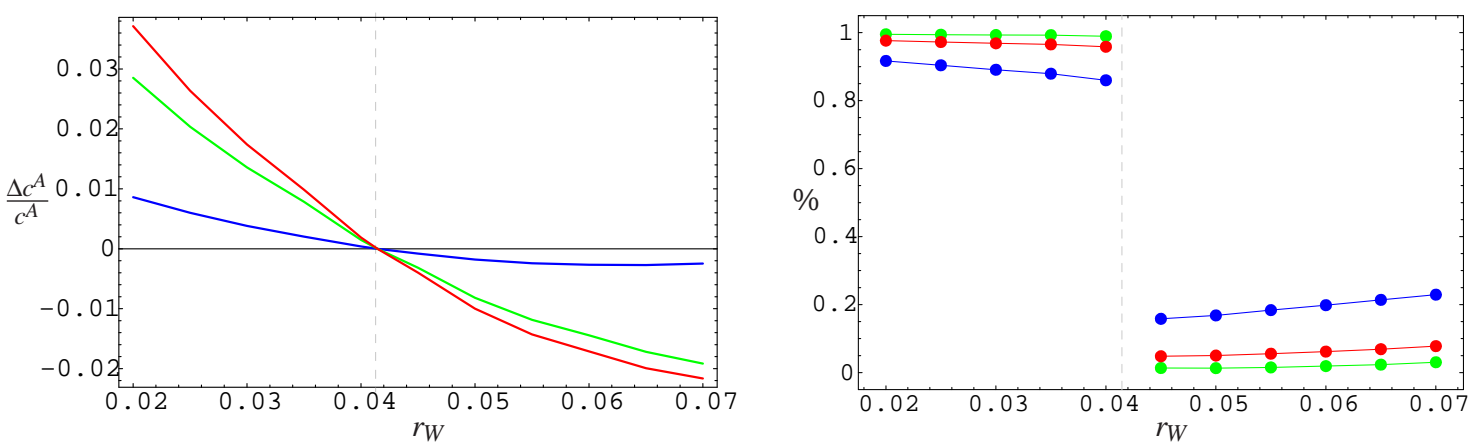

(a) No financial frictions, $\phi \sim \infty$
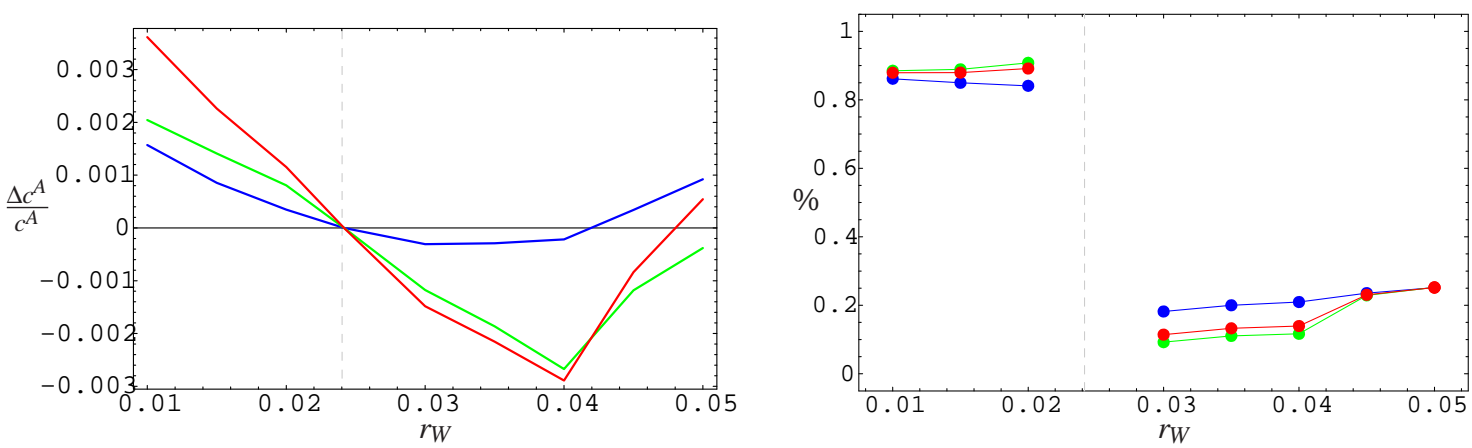

(b) Financial frictions, $\phi=1$
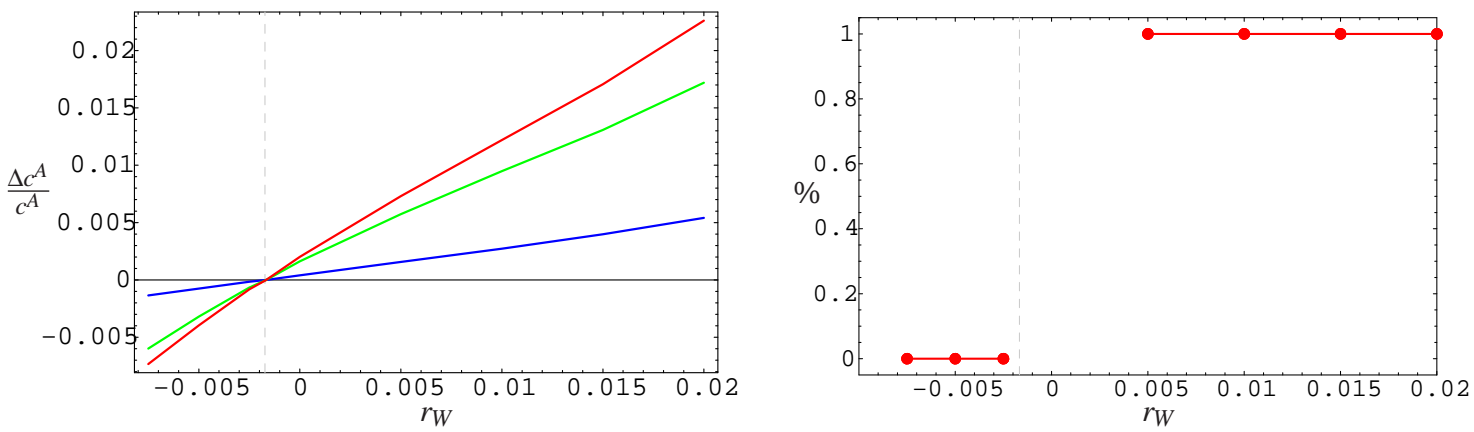

(c) Complete financial frictions, $\phi=0$

Figure 5: Welfare Effects of Financial Integration, total (red), worker (green), entrepreneurs (blue)

in the first two cases, whereas both occupational groups benefit in the latter, workers gaining even more than business owners.

The welfare results are reflected in the observed voting behavior. In the frictionless economy, political support for financial integration is below ten percent over the society as a whole, at maximum 20 percent for entrepreneurs and nil for workers, only rising above the zero level for very large initial interest rate spreads. Political support for financial integration is only slightly bigger for the case of $\phi=1$, ranging from $10-35 \%$. Again, integration receives larger support from the entrepreneurial class. Generally, support is slightly increasing for larger initial differentials between 

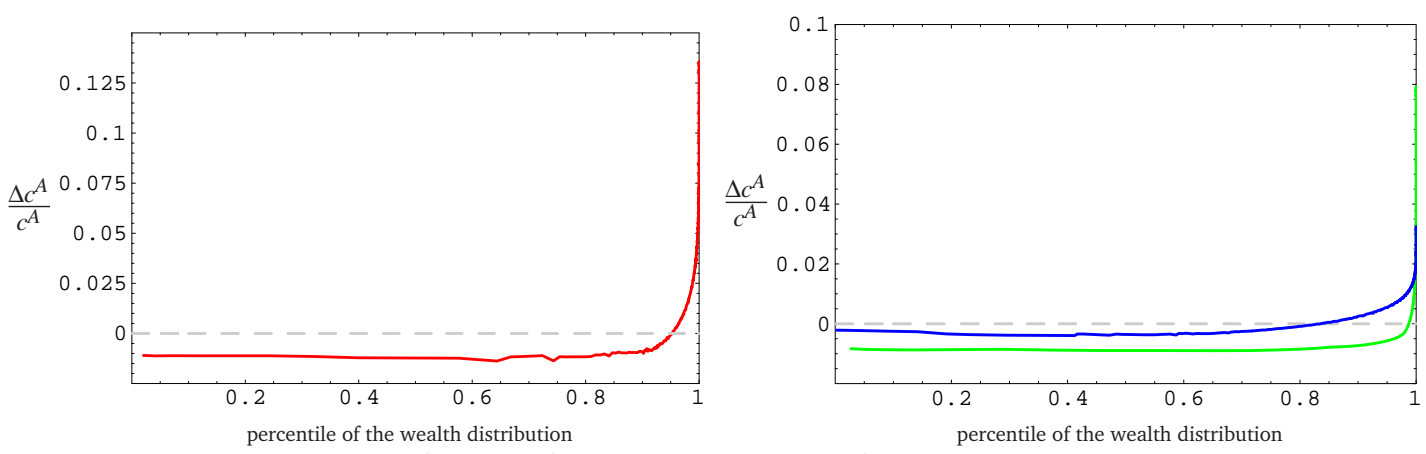

(a) No financial frictions, $\phi \sim \infty, r$ rises from $0.0415 \rightarrow 0.055$
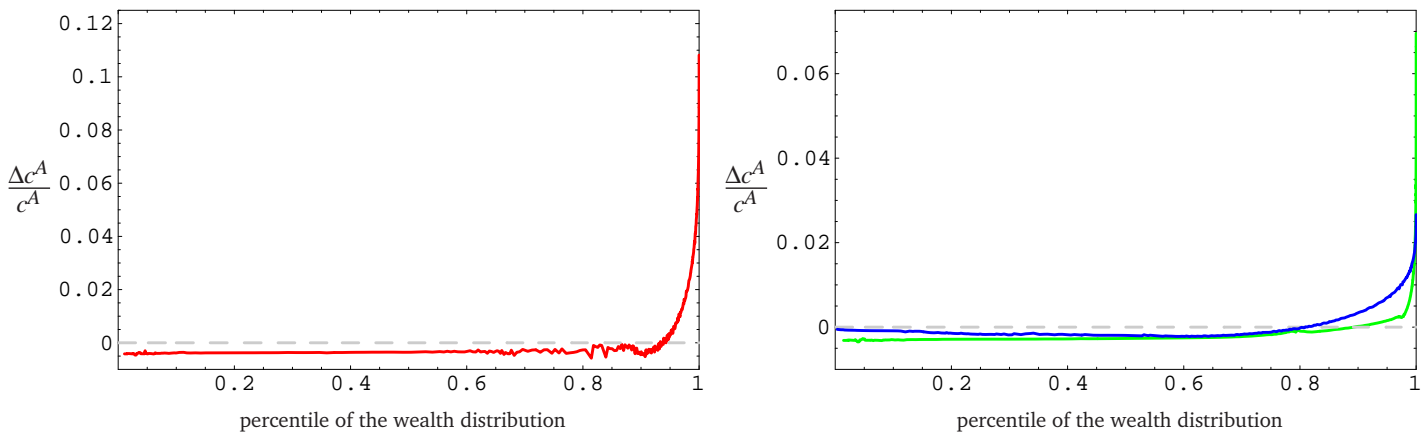

(b) Financial frictions, $\phi=1, r$ rises from $0.0242 \rightarrow 0.035$
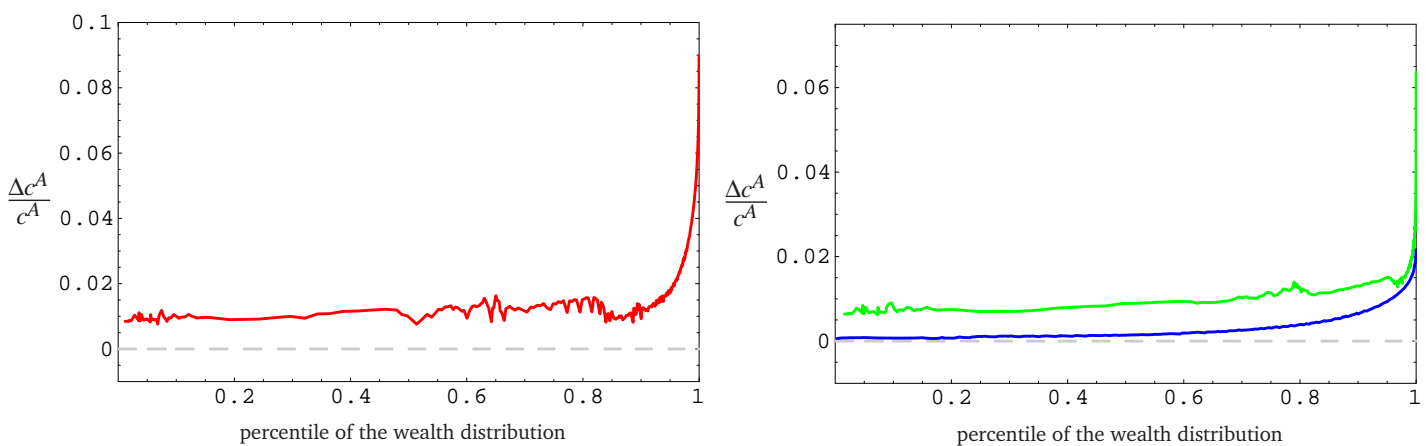

(c) Complete financial frictions, $\phi=0, r$ rises from $-0.00167 \rightarrow 0.01$

Figure 6: Decomposing Welfare Effects of Financial Integration, total (red), worker (green), entrepreneurs (blue)

the autarky interest rate and the world rate. However, a strong majority of households would rather prefer autarky to integration in economies with less tight or no financial frictions, whereas integration is supported unanimously by all groups in the case of complete frictions.

For a deeper understanding of the welfare consequences, we now decompose individual welfare gains and losses with respect to percentiles in the wealth distribution. Relatively wealthier agents are expected to gain most from international integration. They receive a comparably large fraction in total income from riskless interest payments on capital and now benefit from higher returns to foreign assets. 
Figure 6 displays the numerical results. The left-hand panels depict the distribution of welfare gains or losses over the wealth distribution for the society as a whole. The right-hand panels decompose the results with respect to both occupational classes. Figure 6(a) shows that only the topmost five percent of households in the wealth distribution actually gain from international integration in the frictionless economy, even though higher interest rates lead to an increase in aggregate accumulation and GNP. The top group mainly consists of business owners, with only a small fraction of consistently highly productive and therefore rich workers. A huge majority of the population looses from international integration and the associated decline in aggregate and sectoral production, because they have not accumulated sufficient wealth to compensate for the income loss with interest payments from foreign assets. Even for the relatively richer entrepreneurs, only the top quintile benefits from integration. This explains the overall relatively low level of political support for capital market liberalization.

We obtain a similar picture for the case of $\phi=1$, although effects are mitigated here due to the smaller decline in aggregate GDP. Roughly the top ten percent of workers and the top quintile of entrepreneurs benefit from integration. The majority of the populations suffers welfare losses. The decomposed welfare gains and losses also explain the result from Figure 6(b) that-even though the aggregate welfare effect is positive for large initial differentials between the domestic and the world rate-political support remains well below one third of the population. The welfare gains for the top five percent richest households (amounting at max to more than a ten percent increase in consumption) outweigh the cumulated welfare losses of the remaining $95 \%$ of the population. All households could potentially benefit from international integration, if the society were able to implement and conduct a scheme of compensating payments.

Figure 6(c) shows that in the case of a completely constrained economy $(\phi=0)$ households over the entire wealth distribution benefit from capital market liberalization, explaining the unanimous support for international integration. Workers benefit more than business owners especially in the lower percentiles of the wealth distribution. This can be explained with the substantial increase in the wage rate $(8.4 \%$, see Table 4) and associated wage incomes, whereas average firm sizes and profits decline. Still, the picture remains one of a very unequal distribution of welfare changes, the very rich by far being the ones who benefit most from liberalization.

\section{Concluding Remarks}

In this paper, we examine the consequences of international financial integration in a two-sector heterogeneous-agent dynamic general equilibrium model of occupational choice with financial constraints and idiosyncratic risks. We discuss the macroeconomic and distributional effects of financial market integration for small economies which differ only with respect to the tightness of constraints on the domestic credit market. Workers and firm owners are subject to idiosyncratic shocks. Entrepreneurship in the intermediate goods industry is the riskier occupation. In addition to 
general borrowing limits which affect the entire household sector, our model features financing constraints in the non-corporate sector. The stationary wealth distribution generated in the model is consistent with empirical findings.

As a general result, we find that tighter financial constraints or higher entrepreneurial risk on the domestic level cause substantial losses in aggregate output and lower the equilibrium capital return of the closed economy. The latter effect can mainly be attributed to the inefficient allocation of capital across sectors.

In our model, countries which are characterized by tighter domestic constraints will ultimately export capital. This stands in contrast to the widely acknowledged view in the literature that capital account liberalization relaxes financial constraints and causes capital inflows, but can be reconciled with empirical evidence for some developing countries. To this extent our model contributes to the line of research by Gertler and Rogoff (1990), Boyd and Smith (1997), Matsuyama (2004, 2005), or more recently Caballero et al. (2008), Mendoza et al. (2009), and Antunes and Cavalcanti (2014).

Our analysis focuses on economies, where the domestic equilibrium return under autarky is lower than the world return under liberalized capital markets. The general equilibrium nature of our model, where optimal firm sizes and the demand for credit are determined endogenously, gives rise to interesting implications regarding the macroeconomic effects of capital market liberalization. The response of GDP strongly depends on the tightness of financial frictions, being negative for either no or more lax constraints and positive if access to external financing is not available. Contrary, GNP always rises due to the inflow of returns to foreign investments.

The ambiguous sign in the response of aggregate output can be traced back to two important adjustments in the intermediate sector. Firstly, international integration affects occupational choice, the number of entrepreneurs being larger in the open economy. Countries with tighter frictions benefit from a positive wealth effect of integration. A higher world return to capital reinforces accumulation, thereby indirectly weakening the negative impact financial constraints have as a barrier to entrepreneurship. Secondly, average firm sizes decline. Depending on the tightness of financial constraints, total industry output either grows or shrinks in the course of liberalization, translating into either a productivity increase or decline in the production of final output.

The ambiguity of results carries over to the welfare analysis. Countries with severe credit market frictions may actually benefit from integration, whereas lessconstrained economies experience welfare losses. This result is due to the fact that welfare gains and losses generally are very unequally distributed in the underlying heterogeneous-agent economy. The uppermost percentiles always gain from integration, irrespective of the tightness of constraints, because they benefit most from the corresponding increase in the interest rate. All agents gain in the economy with the most tight constraints, because of an increase in both factor prices, in GDP, in wealth and associated safe returns, which lower total income risk.

There are many important issues this paper does not address. In its present form there is no trade in output goods, and all trade is financial. Taking account of in- 
ternational trade will be the next step of our research. It is a worthwhile extension to consider a multi-country model, where the world interest rate is determined endogenously in equilibrium. This allows us discuss the magnitude of macroeconomic effects from financial integration in more detail. Last, the paper explicitly assumes that capital market liberalization does not affect the tightness of domestic constraints, an assumption which could also be relaxed in future research.

\section{References}

Aghion, Philippe, Fally, Thibault, and Scarpetta, Stefano (2007), Credit Constraints as a Barrier to the Entry and Post-entry Growth of Firms, Economic Policy, October 2007, 731-779.

Aiyagari, S. Rao (1994), Uninsured Idiosyncratic Risk and Aggregate Saving, Quarterly Journal of Economics, 109 (3), 659-684.

Angeletos, George-Marios and Panousi, Vasia (2011), Financial Integration, Entrepreneurial Risk and Global Dynamics, Journal of Economic Theory, 146, 863-896.

Antunes, António and Cavalcanti, Tiago (2014), The Welfare Gains of Financial Liberalization: Capital Accumulation and Heterogeneity, Journal of the European Economic Association, p. (forthcoming).

Aoki, Kosuke, Benigno, Gianluca, and Kiyotaki, Nobuhiro (2009), Adjusting to Capital Account Liberalization.

Banerjee, Abhijit V. and Newman, Andrew F. (1993), Occupational Choice and the Process of Development, Journal of Political Economy, 101, 274-298.

Bencivenga, Valerie R. and Smith, Bruce D. (1993), Some Consequences of Credit Rationing in an Endogenous Growth Model, Journal of Economic Dynamics and Control, 17, 97-122.

Bernanke, Ben, Gertler, Mark, and Gilchrist, Simon (1998), The Financial Accelerator in a Quantitative Business Cycle Framework, NBER Working Paper 6455, National Bureau of Economic Research, Cambridge, MA.

Boháček, Radim (2006), Financial Constraints and Entrepreneurial Investment, Journal of Monetary Economics, 53, 2195-2212.

- (2007), Financial Intermediation with Credit Constrained Agents, Journal of Macroeconomics, 29, 741-759.

Boyd, John H. and Smith, Bruce D. (1997), Capital Market Imperfections, International Credit Markets, and Nonconvergence, Journal of Economic Theory, 73, 335364.

Buera, Francisco J and Shin, Yongseok (2009), Productivity Growth and Capital Flows: The Dynamics of Reforms, NBER Working Paper 15268, National Bureau of Economic Research, Cambridge, MA.

Caballero, Ricardo J., Farhi, Emmanuel, and Gourinchas, Pierre-Olivier (2008), An Equilibrium Model of "Global Imbalances" and Low Interest Rates, American Economic Review, 98 (1), 358-393. 
Cagetti, Marco and De Nardi, Mariacristina (2006a), Entrepreneurship, Frictions, and Wealth, Journal of Political Economy, 114 (5), 835-870.

- (2006b), Wealth Inequality: Data and Models, NBER Working Paper 12550, National Bureau of Economic Research, Cambridge, MA.

Carroll, Christopher D. (1997), Buffer-Stock Saving and the Life Cycle/Permanent Income Hypothesis, Quarterly Journal of Economics, 112 (1), 1-56.

Clemens, Christiane (2006), Monopolistic Competition and Entrepreneurial RiskTaking, Economics Letters, 93 (1), 68-74.

- (2008), Imperfect Competition and Growth with Entrepreneurial Risk, German Economic Review, 9 (2), 179-205.

Clemens, Christiane and Heinemann, Maik (2006), On the Effects of Redistribution on Growth and Entrepreneurial Risk-Taking, Journal of Economics, 88 (2), 131158.

- (2010), On Entrepreneurial Risk-Taking and the Macroeconomic Effects of Financial Constraints, Journal of Economic Dynamics and Control, 34, 1610-1626.

Domeij, David and Heathcote, Jonathan (2004), On the Distributional Effects of Reducing Capital Taxes, International Economic Review, 45 (2), 523-554.

Evans, David S. and Jovanovic, Boyan (1989), An Estimated Model of Entrepreneurial Choice under Liquidity Constraints, Journal of Political Economy, 97 (4), 808-827.

Evans, David S. and Leighton, Linda S. (1989), Some Empirical Aspects of Entrepreneurship, American Economic Review, 79 (3), 519-535.

Gentry, William M. and Hubbard, R. Glenn (2004), Entrepreneurship and Household Saving, Advances in Economic Analysis and Policy, 4 (1), Article 8.

Gertler, Mark and Rogoff, Kenneth (1990), North-South Lending and Endogenous Domestic Capital Market Inefficiencies, Journal of Monetary Economics, 26, 245266.

Gourinchas, Pierre-Olivier and Jeanne, Olivier (2006), The Elusive Gains from International Financial Integration, Review of Economic Studies, 73, 715-741.

- (2007), Capital Flows to Developing Countries: The Allocation Puzzle, NBER Working Paper 13602, National Bureau of Economic Research, Cambridge, MA.

Greenwood, Jeremy and Jovanovic, Boyan (1990), Financial Development, Growth, and the Distribution of Income, Journal of Political Economy, 98, 1076-1107.

Guvenen, Fatih (2009), An Empirical Investigation of Labor Income Processes, Review of Economic Dynamics, 12, 58-79.

Holtz-Eakin, D., Joulfaian, D., and Rosen, Harvey S. (1994a), Entrepreneurial Decisions and Liquidity Constraints, Rand Journal of Economics, 25 (2), 334-347.

- (1994b), Sticking it Out: Entrepreneurial Survival and Liquidity Constraints, Journal of Political Economy, 102 (1), 53-75. 
Huggett, Mark (1993), The Risk-Free Rate in Heterogeneous-Agent IncompleteInsurance Economies, Journal of Economic Dynamics and Control, 17 (5-6), 953969.

Kanbur, S. M. (1979), Of Risk Taking and the Personal Distribution of Income, Journal of Political Economy, 87, 769-797.

Kihlstrom, Richard E. and Laffont, Jean-Jacques (1979), A General Equilibrium Entrepreneurial Theory of Firm Formation based on Risk Aversion, Journal of Political Economy, 87, 719-748.

King, Robert G. and Levine, Ross (1993a), Finance and Growth: Schumpeter Might be Right, Quarterly Journal of Economics, 108, 717-738.

- (1993b), Finance, Entrepreneurship, and Growth, Journal of Monetary Economics, $32,513-542$.

King, Robert G. and Rebelo, Sergio T. (1999), Resuscitating Real Business Cycles, in: John B. Taylor and Michael Woodford (eds.), Handbook of Macroeconomics, North-Holland, Amsterdam, vol. Ib, pp. 927-1007.

Lane, Philip R. and Milesi-Ferretti, Gian Maria (2007), The external wealth of nations mark II: Revised and extended estimates of foreign assets and liabilities, 19702004, Journal of International Economics, 73 (2), 223-250.

Lucas, Robert E. (1990), Why Doesn't Capital Flow from Rich to Poor Countries?, American Economic Review, 80 (2), 92-96.

Matsuyama, Kiminori (2004), Financial Market Globalization, Symmetry-Breaking and Endogenous Inequality of Nations, Econometrica, 72 (3), 853-884.

- (2005), Credit Market Imperfections and Patterns of International Trade and Capital Flows, Journal of the European Economic Association, 3 (2-3), 714-723.

Meh, Césaire A. (2005), Entrepreneurship, Wealth Inequality, and Taxation, Review of Economic Dynamics, 8, 688-719.

Mendoza, Enrique G., Quadrini, Vincenzo, and Ríos-Rull, José-Víctor (2009), Financial Integration, Financial Development, and Global Imbalances, Journal of Political Economy, 117 (3), 371-416.

Minniti, Maria, Bygrave, William D., and Autio, Erkko (2005), Global Entrepreneurship Monitor. 2005 Executive Report.

Obstfeld, Maurice (1994), Evaluating Risky Consumption Paths: The Role of Intertemporal Substitutability, European Economic Review, 38, 1471-1486.

OECD (2000), OECD Employment Outlook 2000, OECD Publishing, Paris.

Prasad, Eswar, Rajan, Raghuram G., and Subramanian, Arvind (2006), Patterns of International Capital Flows and Their Implications for Economic Development, in: Federal Reserve Bank of Kansas City (ed.), The New Economic Geography: Effects and Policy Implications, Kansas City, Missouri, pp. 119-158.

Quadrini, Vincenzo (1999), The Importance of Entrepreneurship for Wealth Concentration and Mobility, Review of Income and Wealth, 45 (1), 1-19. 
- (2000), Entrepreneurship, Saving and Social Mobility, Review of Economic Dynamics, 3 (1), 1-40.

Romer, Paul M. (1990), Endogenous Technological Change, Journal of Political Economy, 98 (5), S71-S102.

Rouwenhorst, K. Geert (1995), Asset Pricing Implications of Equilibrium Business Cycle Models, in: Thomas F. Cooley (ed.), Frontiers of Business Cycle Research, Princeton University Press, Princeton, pp. 294-330.

Sandri, Damiano (2009), Growth and Capital Flows with Risky Entrepreneurship.

Storesletten, Kjetil, Telmer, Chris, and Yaron, Amir (2001), How Important Are Idiosyncratic Shocks? Evidence from Labor Supply, AEA Papers and Proceedings, 91 (2), 413-417.

Storesletten, Kjetil, Telmer, Chris I., and Yaron, Amir (2004), Cyclical Dynamics in Idiosyncratic Labor Market Risk, Journal of Political Economy, 112 (3), 695-717.

Vale, Steven (2006), The International Comparability of Business Start-Up Rates. Final Report, OECD Statistics Working Paper STD/DOC(2006)4, OECD, Paris. 